This item was submitted to Loughborough's Research Repository by the author.

Items in Figshare are protected by copyright, with all rights reserved, unless otherwise indicated.

\title{
Biocatalytic membrane reactors (BMR)
}

PLEASE CITE THE PUBLISHED VERSION

http://dx.doi.org/10.1515/psr-2015-0015

\section{PUBLISHER}

(c) Walter de Gruyter GmbH

\section{VERSION}

VoR (Version of Record)

\section{PUBLISHER STATEMENT}

This work is made available according to the conditions of the Creative Commons Attribution-NonCommercialNoDerivatives 4.0 International (CC BY-NC-ND 4.0) licence. Full details of this licence are available at: https://creativecommons.org/licenses/by-nc-nd/4.0/

\section{LICENCE}

CC BY-NC-ND 4.0

\section{REPOSITORY RECORD}

Vladisavljevic, Goran T.. 2016. "Biocatalytic Membrane Reactors (BMR)". figshare. https://hdl.handle.net/2134/20518. 


\section{Goran T. Vladisavljević \\ 2 Biocatalytic membrane reactors (BMR)}

\section{Nomenclature}

\begin{tabular}{|c|c|}
\hline \multicolumn{2}{|c|}{ Abbreviations of Chemicals } \\
\hline AAm & acrylamide \\
\hline 6-APA & 6-aminopenicillanic acid \\
\hline ATEE & $\mathrm{N}$-acetyl tyrosine ethyl ester \\
\hline bPG & benzylpenicillin \\
\hline CDI & carbonyl diimidazole \\
\hline cis-DE & cis-1,2-dimethylcyclohex-4-ene-1,2-dicarboxylate \\
\hline DCP & 2,4-dichlorophenol \\
\hline DD & dodecane \\
\hline HT & hydrotalcite \\
\hline 1-PEA & 1-phenylethyl acetate \\
\hline PAA & poly(acrylic acid) \\
\hline PhAA & phenylacetic acid \\
\hline PAN & polyacrylonitrile \\
\hline PBA & poly(normal-butyl acrylate) \\
\hline PEI & polyethyleneimine \\
\hline PES & polyethersulfone \\
\hline PET & poly(ethylene terephthalate) \\
\hline PFMD & perfluoromethyldecalin \\
\hline PDMS & polydimethylsiloxane \\
\hline POPC & 1-palmitoyl-2-Oleoyl-sn-Glycero-3-Phosphocholine \\
\hline POPS & 1-palmitoyl-2-Oleoyl-sn-Glycero-3-Phospho-L-Serine \\
\hline PS & polysulfone \\
\hline PP & polypropylene \\
\hline PTFE & polytetrafluoroethylene \\
\hline SO & silicone oil \\
\hline $\mathrm{T}$ & toluene \\
\hline TG & triglycerides \\
\hline THF & tetrahydrofuran \\
\hline TPP & tripolyphosphate \\
\hline \multicolumn{2}{|c|}{ Other abbreviations } \\
\hline EMBR & extractive membrane bioreactor \\
\hline BEMBR & biphasic extractive membrane bioreactor \\
\hline FFMD & flow focusing microfluidic device \\
\hline IEM & ion exchange membrane \\
\hline ILM & immobilised liquid membrane \\
\hline MF & microfiltration \\
\hline MSR & membrane separation reactor \\
\hline UF & ultrafiltration \\
\hline PTC & phase-transfer catalysis or catalyst \\
\hline SC & supercritical \\
\hline VOC & volatile organic campound \\
\hline
\end{tabular}




\subsection{Introduction}

The term membrane reactor first began to appear in the chemical engineering literature around 1980 [1]. Although there is no commonly accepted definition of a membrane reactor, the term usually refers to membrane devices whose function is to perform net chemical conversion under conditions in which the unique contacting and separation features of membranes and membrane devices are exploited. In particular, the term membrane reactor is reserved for those processes wherein the membrane functions as more than simply a reactive membrane, i.e. a membrane matrix used for catalyst immobilization [1]. The biocatalytic membrane reactor (BMR) is a device in which biochemical transformations catalyzed by enzymes or cells are combined with permeation or mass transfer through the membrane.

Since the catalytic efficiency of biochemical systems in vivo can often be attributed to the action of membrane-bound enzymes, it is not surprising that membrane-aided biocatalysis using synthetic membranes is an increasingly popular topic of research in engineering circles. As noticed by Matson and Quinn [1], any aspects of the structure and function of biological membranes that have been elucidated over the past several decades make it clear that nature has designed a highly integrated chemical plant that engineers might profitably mimic.

\subsection{Role of membrane in biocatalytic membrane reactors (BMRs)}

The most common types of BMRs are summarized in Fig. 2.1. The role of synthetic membranes in BMRs is to serve: (a) solely as a separation barrier to achieve separation of the product from a biocatalyst; (b) both as a separation barrier and a medium for biocatalyst immobilization; (c) as a medium for creating and maintaining high interfacial area per unit volume to conduct non-dispersive gas/liquid and liquid/liquid mass-transfer processes; and (d) as a medium (carrier) for enzyme or cell encapsulation. If the membrane serves only as a semipermeable barrier, there are two modes of operations with regard to the location of the biocatalyst in the membrane system: (i) The biocatalyst is suspended in a stirred tank reactor and the reaction mixture is continuously brought into contact with the membrane for product removal. In this mode of operation, the stirred tank functions as a stirred tank reactor (STR); (ii) the biocatalyst is suspended only within the membrane module, where a biochemical conversion takes place. In the latter case the membrane acts as a medium for biocatalyst segregation; the membrane module functions as a reactor [2]. If the membrane is a medium for encapsulation, enzymes or whole cells are entrapped within semipermeable micro/nano-particles or vesicles such as liposomes [3], polymersomes [4], colloidosomes [5], microgels [6] and polymeric microspheres [7]. Biocatalyst can also be immobilized in or onto the microporous membrane by physical entrapment [8], gela- 


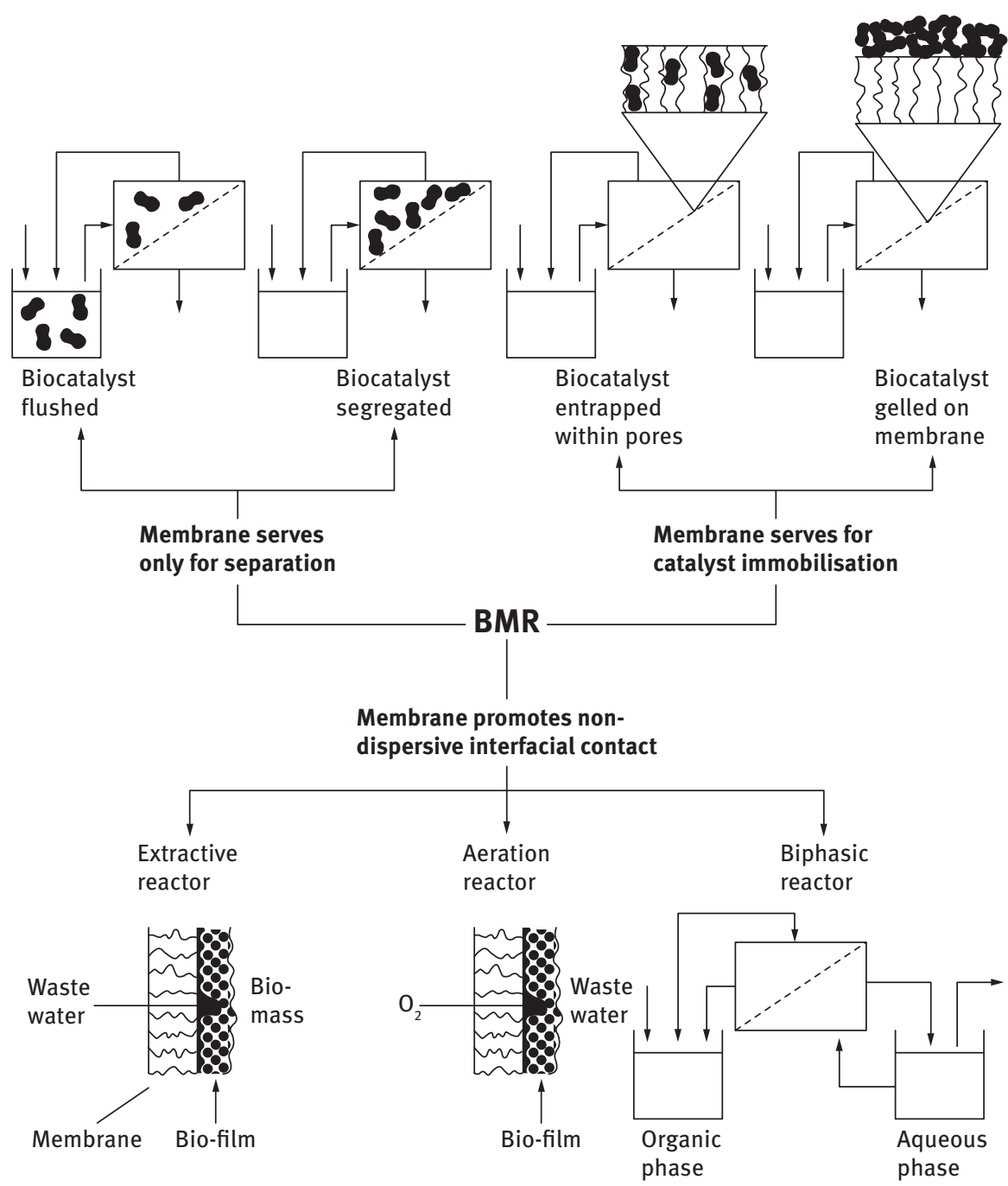

Fig. 2.1: Classification of biocatalytic membrane reactors ( - substrate, $B$ - water soluble product, $\because \mathrm{B} \square-$ oil-soluble product).

tion [9], physical adsorption [10], ionic binding [11], covalent binding [12] or copolymerization [13].

In addition to the type of immobilization, BMRs can be classified according to their operational mode into ultrafiltration (UF) or microfiltration (MF) membrane reactors, biphasic (organic and aqueous) membrane reactors, membrane aeration reactors and extractive membrane reactors [14]. UF membrane reactors are used when the substrate has a significantly higher molecular weight compared to that of the product, and both substrate and product are soluble in the same solvents. In that case, the substrate 
molecules are transferred to the enzyme immobilized in or onto the membrane, but they cannot pass through the membrane, whilst the product can freely pass through and be recovered from the permeate side of the membrane. If the substrate and product have a similar molecular size, they can both pass through the membrane. In that case, the membrane type and operating conditions should be chosen in such a way that the permeation rate matches the reaction rate to ensure that the substrate will be fully converted into the product as it passes through the membrane. If the substrate has a different solubility to the product (e.g. an oil-soluble ester and its water-soluble hydrolysis products), a biphasic membrane reactor might be a good choice [15]. In this type of reactor system, the enzyme-loaded membrane is located between two immiscible liquid phases, an organic and an aqueous phase. The organic phase, which contains the substrate, circulates on one side of the membrane; the substrate is diffused to the hydrophilic membrane wetted by the aqueous phase, where the reaction takes place in an aqueous environment, and the product is extracted by the aqueous phase circulated on the other side of the membrane. If the biocatalyst is selective for only one of the two enantiomers present in a racemic mixture, a biphasic system is particularly useful for production of pure enantiomers [16]. Pure isomers are required in biomedical applications, where they have to be administered to humans and animals.

The membrane in BMRs may also serve as a medium for a bubbleless transfer of gas (oxygen or air) into a bioreactor to augment microbial degradation [17] or as a medium for a non-dispersive extraction of organic pollutants from wastewater [18].

Another classification of membrane reactors is based on the relative position of the two most important elements of the reactor: the membrane and the catalyst. The three main configurations are shown in Fig. 2.2: (a) the catalyst is suspended in a reaction mixture separated from the membrane; (b) the catalyst is suspended in a liquid core which is surrounded by the membrane (a core-shell microcapsule); and (c) the catalyst is incorporated within the membrane, i.e. the membrane is inherently catalytic. The membrane in core-shell microcapsules can be composed of lipid bilayers, a hydrogel, synthetic polymer, fused particles, etc. Hybrid systems are also possible, for example the matrix-type porous microcapsule shown in Fig. 2.2 (d) combines the structures shown in Fig. 2.2 (b) and (c). Although membranes are more expansive as enzyme supports than porous beads shown in Fig. 2.2(b) and (d), their advantages may in many applications overcome this limitation (Tab.2.1). Membranes permit a much higher order and generally smaller scale of organization than do particles [1]. The fluids on either side of a membrane can be separated by appropriate membrane module design; this then provides the engineer with an additional degree of freedom in reactor design. While there is only a single interface between a porous catalyst particle and the solution surrounding it (Fig. 2.2(d)), two membrane/solution interfaces and two liquid compartments exist that can be exploited in a number of ways. For example, a membrane reactor might be used to catalyze the reaction between two reactants present in separate streams that cannot be mixed for some reason, perhaps to 
avoid a subsequent separation problem or a non-catalytic side reaction, or reactants or products are soluble in different solvents (organic and aqueous). When porous beads are used, separation of the products from the reactants is impossible because there is only one liquid compartment. For the same reason, the product concentration in the porous beads reactor is limited by the stoichiometry of the reaction, conversion and reactant concentrations. When a catalyst is encapsulated within a porous membrane, the product concentration can be controlled by the flow rate ratio of the product and feed stream, which makes it possible to achieve high product concentrations irrespective of the reactant concentration. In addition, the rate of mass transfer within a porous membrane can be enhanced by creating a pressure difference across the membrane, which will lead to convective transport of species across the membrane. On the other hand, within a porous bead, mass transfer can only occur by molecular diffusion.

Tab. 2.1: Comparison of porous membranes and porous particles as enzyme supports.

\begin{tabular}{lll}
\hline Function & \multicolumn{2}{l}{ Type of catalyst support } \\
\cline { 2 - 3 } & Membrane & $\begin{array}{l}\text { Porous particles } \\
\text { or capsules }\end{array}$ \\
\hline Immobilization & Yes & Yes \\
Mass transfer by diffusion & Yes & Yes \\
Mass transfer by convection & Yes & No \\
Liquid/liquid separation & Yes & No \\
Enzyme/product separation & Yes & No \\
Product concentration & Yes & No \\
\hline
\end{tabular}

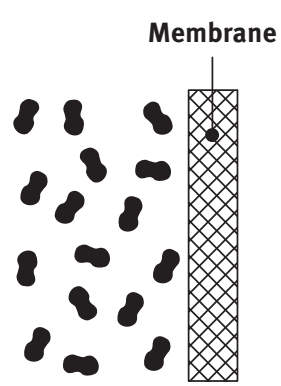

(a)

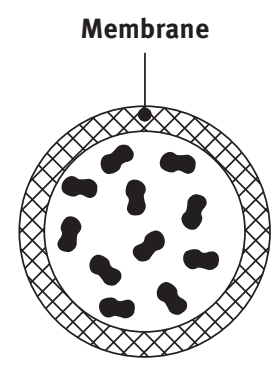

(b)

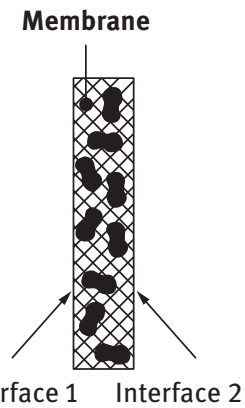

(c)

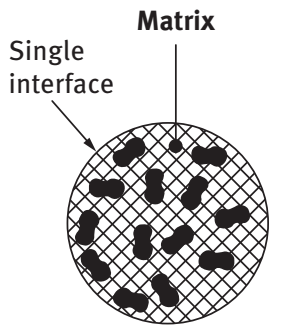

(d)

Fig. 2.2: Typical configurations of membrane biocatalytic reactors according to the relative position of the membrane and the catalyst: (a) the catalyst is physically separated from the membrane; (b) the catalyst is encapsulated in a core-shell microcapsule; (c) the catalyst is incorporated within the membrane wall; (d) the catalyst is encapsulated in a matrix-type microcapsule. 

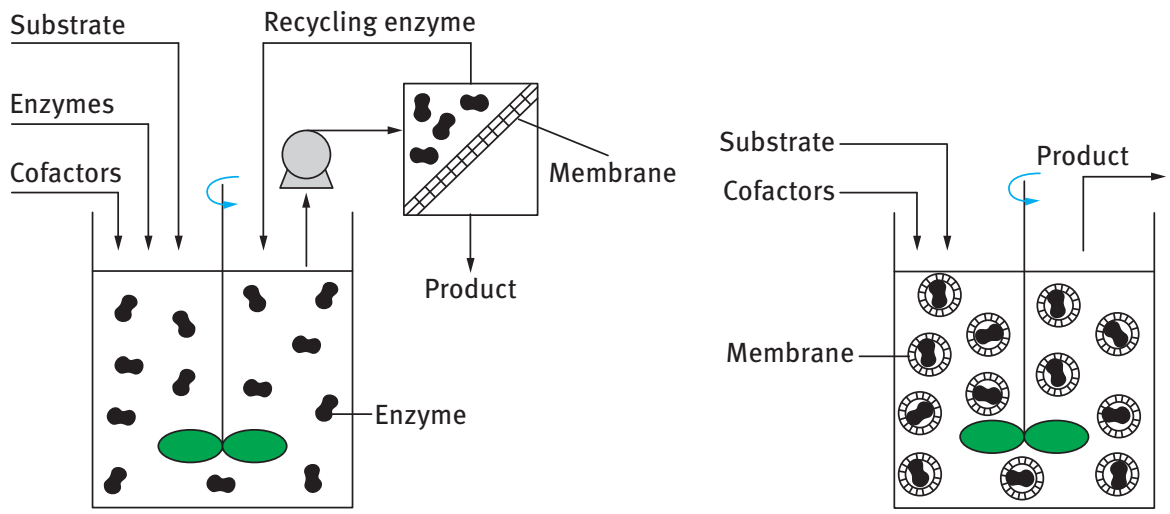

(a)

(b)

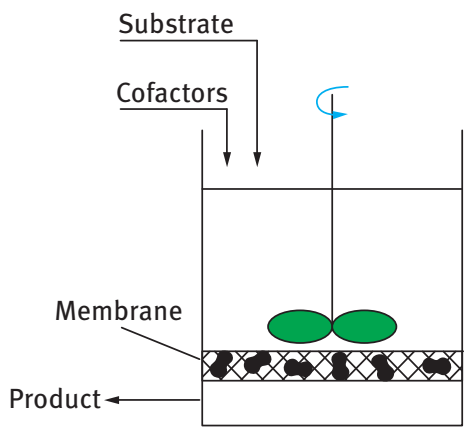

(c)

Fig. 2.3: Typical biocatalytic membrane reactor systems based on configurations shown in Fig. 2.2:

(a) Stirred tank reactor combined with membrane module for enzyme recycle and product withdrawal; (b) Stirred tank with enzymes entrapped within core-shell microcapsules; (c) Stirred tank with enzymes immobilized within the membrane matrix.

Fig. 2.3 shows typical BMRs based on the configurations presented in Fig. 2.2. The BMR shown in Fig. 2.3 (a) consists of a continuous stirred tank reactor combined with an ultrafiltration (UF) or microfiltration (MF) membrane module for the product removal. The reactor presented in Fig. 2.2(b) is a conventional stirred tank reactor in which biocatalysts are encapsulated within microcapsules with semi-permeable walls. In a membrane immobilization approach shown in Fig. 2.3 (c), enzymes are bound to the membrane by physical adsorption, gel formation, electrostatic deposition or covalent attachment. Substrates are transferred across the membrane wall to the catalyst and the products diffuse from the reaction site to the other side of the membrane; they are recovered here as a permeate. In general, it is the mass-transport resistance that primarily influences the performance of these reaction systems. In order for a reactor to function at its optimal performance, it should work in a reaction-limited regime rather than a diffusion-limited regime. The parameter that can give a measure of this 
condition is the Thiele modulus, which is given by:

$$
\phi=L\left(\frac{r_{\max }}{D_{\mathrm{eff}} K_{m}}\right)^{1 / 2},
$$

where $L$ is the length, $r_{\max }$ is the maximum reaction rate, $K_{m}$ is the Michaelis-Menten constant and $D_{\text {eff }}$ is the effective diffusivity. This has the physical meaning of a ratio between the reaction rate and the diffusion rate. For $\phi \leq 1$, the system is essentially controlled by chemical kinetics and the mass-transfer limitation is negligible [19].

\subsection{Membrane separation reactors (MSRs)}

\subsubsection{Concept}

A membrane separation reactor (MSR) can be considered as a combination of a reaction vessel, either a continuous stirred tank reactor (CSTR) or a batch stirred tank reactor, and a membrane module. The purpose of the membrane is to contain a dissolved or dispersed biocatalyst (enzyme molecules or cells) in the reaction vessel, while products and unreacted permeable reactants are allowed to leave the reactor. In a continuous flow process, the solution is supplied continuously to the vessel, while the product, together with excess solvent, is withdrawn in a feed-and-bleed operation $[14,20,21]$. The process results in the product removal without a loss of the biocatalyst and high-molecular weight substrate. The biocatalytic reaction usually occurs in an aqueous phase, although organic solvents or supercritical $\mathrm{CO}_{2}\left(\mathrm{SC} \mathrm{CO}_{2}\right)$ could be more appropriate medium than water for conversion of hydrophobic substrates [22, 23]. The advantages of using $\mathrm{SC} \mathrm{CO}_{2}$ over organic solvents include environmental, health and safety, and process benefits. The use of $\mathrm{SC} \mathrm{CO}_{2}$ can allow higher mass transfer rates because of the lower viscosity of $\mathrm{SC} \mathrm{CO}_{2}$ compared to that of organic solvents and accompanying high molecular diffusivities. On the other hand, the problem when using biocatalysts in $\mathrm{SC} \mathrm{CO}_{2}$ is that high pressure, law water activity, increased temperature, and pressurization/depressurization steps may adversely affect the catalyst stability and activity.

The main advantages of MSRs over conventional biocatalytic reactors are prolonged biocatalyst activity, reduction in costs and energy due to biocatalyst recycling, greater yields and selectivities due to continual removal of products, higher capacity at the same reactor volume due to high biocatalyst loadings, and simple scale-up to large systems due to modular design of membrane units. In addition, the product stream is typically free from all suspended matter including bacteria and viruses [24]. Along with the complete removal of bacteria and viruses, MSRs are compact devices with a smaller footprint than conventional biocatalytic systems, since they can achieve simultaneous bioconversion, separation and concentration in a single unit. 


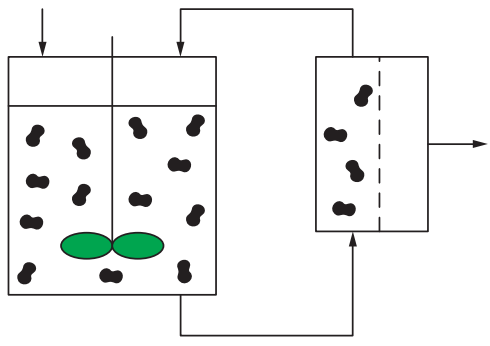

(a)

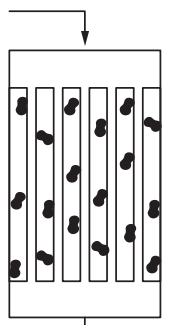

(c)

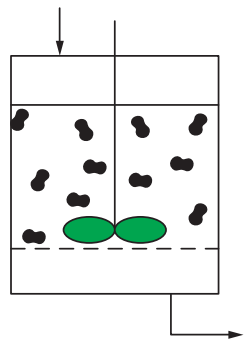

(b)

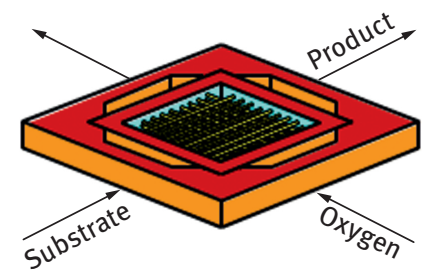

(d)

Fig. 2.4: Different modes of operation of membrane separation reactors: (a) External membrane loop ('sidestream'); (b) Internal membrane ('submerged'); (c) segregation in a single-set hollow fiber module; (d) segregation in a two-set hollow fiber module.

The separation of low-molecular-weight products from biocatalysts can be achieved using either an external loop with a separate membrane module (Fig. 2.4 (a)) or a membrane submerged inside the reaction vessel (Fig. 2.4 (b)) [25, 26]. In the set-up illustrated in Fig. 2.4 (a), the content of the vessel is circulated continuously through the external membrane module where an enzyme-free permeate is removed from the reaction mixture. The submerged system differs in that there is no recirculation loop and the separation occurs within the bioreactor. In either case, surface shear and/or backflushing is applied to control cake formation and fouling. In the submerged system, the membrane is mounted in the stirred tank; stirring or bubbling is usually applied to produce the surface shear and the permeate is removed by suction with a vacuum pump or by a compressed gas. The membranes used in the submerged systems are typically hollow fibers or flat sheets, aligned vertically or horizontally. When the surface shear is provided by bubbling, gas is introduced below the membrane assembly and is distributed to optimize the air scouring action across the vertical membrane surface. The two methods based on internal or external membranes in conjunction with the reaction vessel both have their advantages and drawbacks. The external loop membrane can easily be changed if severe clogging occurs. Furthermore, in the external membrane loop it is easier to increase the filtration area if necessary. On the other hand, when operating with high biocatalyst densities using an external loop, 
there is a risk of the occurrence of oxygen limitation. One way to reduce this risk is to increase the rate of circulation through the membrane module, but high shear stress can damage shear-sensitive biocatalysts.

One option to prevent damages to shear-sensitive cells and enzymes is to segregate a biocatalyst within a hollow fiber membrane module. In the system shown in Fig. 2.4 (c), the feed stream is introduced through the lumen of the fibers and biocatalysts are localized in the extra-capillary space, where the reaction proceeds in a low shear-stress environment. Substrate molecules diffuse through the walls of the fibers from inside to outside and the products diffuse in the opposite direction. A transverse flow hollow fiber module containing two independent sets of hollow fibers placed within the same frame element (Fig. $2.4(\mathrm{~d})$ ) is a potential alternative to the conventional parallel flow module, suitable to meet very high oxygen demands in the reactor. In this case, substrate is fed and products are removed via the lumen of one set of hollow fibers and oxygen is supplied through the lumen of the second set of the fibers, while the biocatalyst is dispersed in the extra-capillary space. An additional advantage of this design is that the membrane area can easily be increased by adding more frame elements, similar to a plate-and-frame-filter press [27].

The main benefits of using MSRs are schematically shown in Fig. 2.5 [28].

(a) Increase of conversion in reversible reactions: the major role of the membrane here is to selectively remove a product of a reversible reaction from the reaction mixture (product C in Fig. 2.5 (a), thereby shifting the equilibrium towards higher product yields (i.e. higher conversions of $\mathbf{A}$ ). The reactions of this type include dehydrogenation and esterification reactions.

(b) Enhancement of selectivity through controlled product removal: the role of the membrane in Fig. 2.5 (b) is to suppress the further decomposition of a desirable intermediate product (C) by removing this product through the membrane.

(c) Enhancement of selectivity through controlled addition of reactants: in this approach, the concentration of a reactant $B$ in the reaction mixture $(A+B)$ is kept low by a controlled supply of $\mathbf{B}$ through the membrane, so that the rate of formation of a by-product $\mathbf{D}$ is kept low (Fig. 2.5 (c)). Controlled addition can also be useful to prevent catalyst deactivation and to avoid a dangerous increase of temperature in exothermic reactions. Partial oxidation of hydrocarbons is the most relevant application of this approach where a controlled addition of the oxidant through the membrane results in a better yield of the intermediate oxidation products.

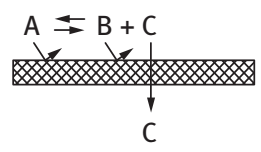

(a)

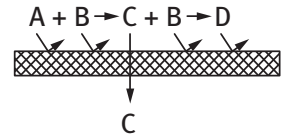

(b)

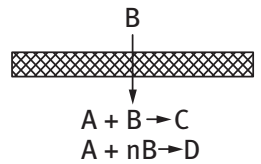

(c)

Fig. 2.5: Major benefits of using membrane reactors: (a) improved conversion; (b), (c) increased selectivity. 


\subsubsection{Application}

A number of nutritionally important amino acids have been synthesized or optically resolved on an industrial scale using enzymatic reactions in membrane separation reactors [1]. Wichmann et al. [29] have conducted multienzyme (multistep) bioconversions with simultaneous cofactor regeneration in a continuously operated MSR shown in Fig. 2.6. For the continuous operation of cofactor dependent systems, it is critically important to retain and regenerate the cofactor in the reaction mixture. The retention of native cofactors such as NAD/NADH by a membrane would require a reverse osmosis membrane that has a very low permeability to water as compared to an UF membrane. Moreover, it would be difficult, if not impossible, to obtain the product without leakage of the cofactor through the membrane, due to the small difference in size between the solvent and the cofactor molecules. This problem was solved by enlarging the cofactor molecule to a size similar to that of the enzyme. It was achieved by covalent attachment of the cofactor $\left(\mathrm{NAD}^{+} / \mathrm{NADH}\right)$ to poly(ethylene glycol) (PEG), a linear polymer with only two terminal reactive groups on the polymer chain, so steric hindrance was low [29]. The PEGylated cofactor was used to catalyze the reductive amination of $\alpha$-ketoisocaproate by L-leucine dehydrogenase (enzyme $\mathrm{E}_{2}$ in Fig. 2.6) to L-leucine. Formate dehydrogenase (enzyme $\mathrm{E}_{1}$ in Fig. 2.6) was used for regeneration of $\mathrm{NAD}^{+}$from NADH. The use of charged UF membranes is an alternative method for the retention of the native coenzyme $\mathrm{NADH}$ in a membrane reactor [30].

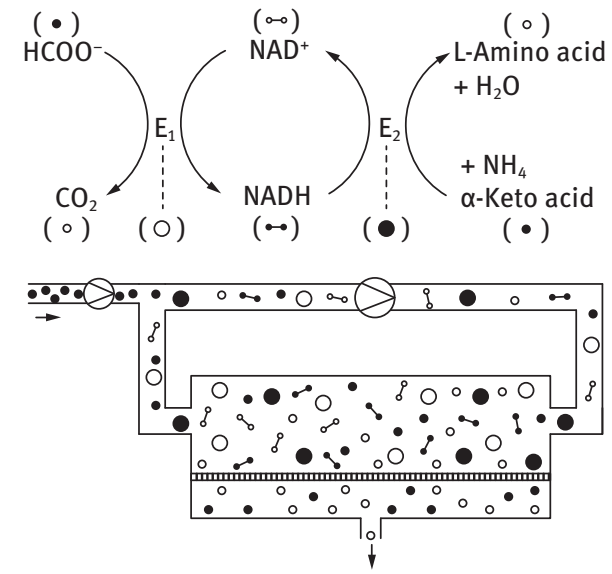

Fig. 2.6: Membrane separation reactor for continuous enzymatic synthesis of L-amino acid from $\alpha$-keto acid with coenzyme (NADH/NAD $\left.{ }^{+}\right)$ regeneration. Adopted from [29].

In addition to the synthesis reactions, membrane reactors are extensively used in the enzymatic hydrolysis of natural macromolecules (starch, cellulose, proteins, pectin, chitosan, etc.), oligo- and di-saccharides, and bioflavonoids, especially for biomedical and pharmaceutical applications (Tab. 2.2) and in the agro-food sector (Tab. 2.3). 
Tab. 2.2: Examples of medical and pharmaceutical applications of membrane reactors ( $\mathrm{CO}=$ cut-off).

\begin{tabular}{|c|c|c|c|c|}
\hline Enzyme or cells & Membrane & Reaction & Purpose & Reference \\
\hline $\begin{array}{l}\text { Arginase, } \\
\text { asparaginase }\end{array}$ & $\begin{array}{l}\text { Hemophan } \\
\text { (cellulose } \\
\text { derivative) }\end{array}$ & $\begin{array}{l}\text { Hydrolysis of } \\
\text { arginine and } \\
\text { asparagines }\end{array}$ & Cancer therapy & Shettigar [31] \\
\hline $\begin{array}{l}\text { Heparinase, } \\
\text { tripsin, pronase }\end{array}$ & $\begin{array}{l}\text { Polyester } \\
\text { membrane }\end{array}$ & $\begin{array}{l}\text { Hydrolysis of } \\
\text { blood toxins, } \\
\text { such as heparin }\end{array}$ & $\begin{array}{l}\text { Removal of } \\
\text { blood toxins } \\
\text { in hemodialasys }\end{array}$ & Ameer et al. [32] \\
\hline Hepatocytes & $\begin{array}{l}\text { Hollow fiber or } \\
\text { flat plate }\end{array}$ & $\begin{array}{l}\text { Liver-specific } \\
\text { functions }\end{array}$ & $\begin{array}{l}\text { Extracorporeal } \\
\text { bioartificial liver } \\
\text { devices }\end{array}$ & $\begin{array}{l}\text { Allen et al. [33] } \\
2001\end{array}$ \\
\hline $\begin{array}{l}\text { Pancreatic } \\
\text { endocrine cells }\end{array}$ & $\begin{array}{l}\text { Nucleopore, } \\
\text { pore size }=0.1 \mu \mathrm{m}\end{array}$ & Insulin secretion & $\begin{array}{l}\text { Bioartificial } \\
\text { pancreas }\end{array}$ & $\begin{array}{l}\text { Ohgawara et al. } \\
\text { [34] }\end{array}$ \\
\hline $\begin{array}{l}\text { Bacterial } \\
\text { protease }\end{array}$ & $\mathrm{PES}, \mathrm{CO}=3 \mathrm{kDa}$ & $\begin{array}{l}\text { Hydrolysis of } \\
\text { whey proteins }\end{array}$ & $\begin{array}{l}\text { Production of } \\
\text { low allergenicity } \\
\text { hydrolysates for } \\
\text { enteral nutrition }\end{array}$ & Guadix et al. [35] \\
\hline $\begin{array}{l}\text { Amidase from } \\
\text { Microbacterium } \\
\text { imperiale }\end{array}$ & $\begin{array}{l}\text { Fluoropolymer, } \\
\mathrm{CO}=20 \mathrm{kDa}\end{array}$ & $\begin{array}{l}\text { Deamidation of } \\
\text { nicotinamide to } \\
\text { nicotinic acid }\end{array}$ & $\begin{array}{l}\text { Production of } \\
\text { nicotinic acid (B- } \\
\text { complex vitamin) }\end{array}$ & $\begin{array}{l}\text { Cantarella et al. } \\
\text { [36] }\end{array}$ \\
\hline $\begin{array}{l}\text { Glucose-fructose } \\
\text { oxidoreductase } \\
\text { from Zymomonas } \\
\text { Mobilis }\end{array}$ & $\begin{array}{l}\text { Milipore, } \\
\mathrm{CO}=10 \mathrm{kDa}\end{array}$ & $\begin{array}{l}\text { oxidation of } \\
\text { glucose }\end{array}$ & $\begin{array}{l}\text { Production of } \\
\text { lactobionic acid } \\
\text { for medical use }\end{array}$ & Satory et al. [37] \\
\hline
\end{tabular}

More recently, membrane reactors have been used successfully for the treatment of wastewaters. The constantly increasing degree of industrialization and urbanization, rising standards of living, increasing population growth and agricultural activities are strongly impacting on the use of available water sources and on the quality of water that is found therein. This exhaustive use of limited resources and energy by modern society implies a need for changes in present and future urban water and wastewater treatment systems [51]. Membrane reactors enable degradation but also the recuperation of valuable components from effluent streams (Tab. 2.4). They are also useful for reusing contaminated process water $[60,61]$. 
Tab. 2.3: Examples of agro-food applications of membrane reactors ( $\mathrm{CO}=$ cut-off).

\begin{tabular}{|c|c|c|c|c|}
\hline Enzyme & Membrane & Reaction & Purpose & Reference \\
\hline $\begin{array}{l}\text { Trypsin from } \\
\text { bovine pancreas }\end{array}$ & $\begin{array}{l}\text { Cellulose ace- } \\
\text { tate, } C O=3 \mathrm{kDa}\end{array}$ & $\begin{array}{l}\text { Hydrolysis } \\
\text { of caseino- } \\
\text { macropeptide }\end{array}$ & $\begin{array}{l}\text { Production of } \\
\text { peptides for } \\
\text { functional food }\end{array}$ & $\begin{array}{l}\text { Prata-Vidal et al. } \\
\text { [38] }\end{array}$ \\
\hline $\begin{array}{l}\text { Trypsin from } \\
\text { bovine pancreas }\end{array}$ & $\begin{array}{l}\text { Cerasep }^{\circledR} \\
\text { nanofiltration }\end{array}$ & $\begin{array}{l}\text { Hydrolysis } \\
\text { of caseino- } \\
\text { macropeptide }\end{array}$ & $\begin{array}{l}\text { Production of } \\
\text { peptides for } \\
\text { functional food }\end{array}$ & $\begin{array}{l}\text { Martin-Orue } \\
\text { et al. [39] }\end{array}$ \\
\hline $\begin{array}{l}\text { Enzymes from } \\
\text { Trichoderma } \\
\text { reesei fungi }\end{array}$ & $\begin{array}{l}\text { Carbosep }^{\circledR} \mathrm{M} 5, \\
\mathrm{CO}=10 \mathrm{kDa}\end{array}$ & $\begin{array}{l}\text { Hydrolysis of } \\
\text { olive mill solid } \\
\text { residue }\end{array}$ & $\begin{array}{l}\text { Ethanol produc- } \\
\text { tion }\end{array}$ & $\begin{array}{l}\text { Mameri et al. } \\
\text { [40] }\end{array}$ \\
\hline $\begin{array}{l}\text { Glucoamylase } \\
\text { from Aspergillus } \\
\text { niger }\end{array}$ & $\begin{array}{l}\text { Amicon Diaflo }{ }^{\circledR} \\
\text { H1510-43, } \\
\text { CO }=10 \mathrm{kDa}\end{array}$ & $\begin{array}{l}\text { Hydrolysis of } \\
\text { cassava flour } \\
\text { starch }\end{array}$ & $\begin{array}{l}\text { Production of } \\
\text { pure dextrose, } \\
\text { high fructose } \\
\text { syrups, etc. }\end{array}$ & $\begin{array}{l}\text { López-Ulibarri } \\
\text { and Hall [41] }\end{array}$ \\
\hline Glucoamylase & $\begin{array}{l}\text { regenerated } \\
\text { cellulose, } \\
\mathrm{CO}=10 \mathrm{kDa}\end{array}$ & $\begin{array}{l}\text { Hydrolysis of } \\
\text { corn starch }\end{array}$ & $\begin{array}{l}\text { Production of } \\
\text { glucose or mal- } \\
\text { tose syrups }\end{array}$ & $\begin{array}{l}\text { Singh and } \\
\text { Cheryan [42] }\end{array}$ \\
\hline $\begin{array}{l}\beta \text {-Galacto- } \\
\text { sidase from } \\
\text { Kluyveromyces } \\
\text { fragilis }\end{array}$ & $\begin{array}{l}\text { Cuprophan }{ }^{\circledR} \text { and } \\
\text { PS hollow fiber, } \\
\text { CO }=5 \mathrm{kDa}\end{array}$ & $\begin{array}{l}\text { Hydrolysis of } \\
\text { lactose }\end{array}$ & $\begin{array}{l}\text { Milk or whey } \\
\text { delactosization }\end{array}$ & Jurado et al. [43] \\
\hline $\begin{array}{l}\text { naringinase from } \\
\text { Aspergillus niger }\end{array}$ & $\begin{array}{l}\text { Romicon HF } \\
\text { 1.1-43-PM10 }\end{array}$ & $\begin{array}{l}\text { Hydrolysis of } \\
\text { naringin }\end{array}$ & $\begin{array}{l}\text { Debittering of } \\
\text { grapefruit juice }\end{array}$ & $\begin{array}{l}\text { Gray and Olson } \\
{[44]}\end{array}$ \\
\hline $\begin{array}{l}\text { polygalacturo- } \\
\text { nase from } \\
\text { Aspergillus niger }\end{array}$ & $\begin{array}{l}\text { regenerated } \\
\text { cellulose, } \\
\mathrm{CO}=30 \mathrm{kDa}\end{array}$ & $\begin{array}{l}\text { Hydrolysis of } \\
\text { pectin }\end{array}$ & $\begin{array}{l}\text { Clarification of } \\
\text { fruit juice }\end{array}$ & $\begin{array}{l}\text { Bélafi-Bakó et al. } \\
\text { [45] }\end{array}$ \\
\hline $\begin{array}{l}\text { polygalacturo- } \\
\text { nase from } \\
\text { Aspergillus niger }\end{array}$ & $\begin{array}{l}\text { polysulfone, } \\
C O=10 \text { and } \\
50 \mathrm{kDa}\end{array}$ & $\begin{array}{l}\text { Hydrolysis of } \\
\text { pectin }\end{array}$ & $\begin{array}{l}\text { Clarification } \\
\text { of wine and fruit } \\
\text { juice }\end{array}$ & $\begin{array}{l}\text { Rodriguez- } \\
\text { Nogales et al. } \\
{[46]}\end{array}$ \\
\hline $\begin{array}{l}\text { Invertase im- } \\
\text { mobilised on } \\
\text { polystyrene } \\
\text { beads }\end{array}$ & $\begin{array}{l}\text { regenerated } \\
\text { cellulose, } \\
\text { CO }=100 \mathrm{kDa} \\
\text { or } 5 \mu \mathrm{m}\end{array}$ & $\begin{array}{l}\text { Hydrolysis of } \\
\text { sucrose }\end{array}$ & $\begin{array}{l}\text { Production } \\
\text { of high-fructose } \\
\text { syrup }\end{array}$ & $\begin{array}{l}\text { Tomotani and } \\
\text { Vitolo [47] }\end{array}$ \\
\hline $\begin{array}{l}\text { xylose reductase } \\
\text { from Candida } \\
\text { tenuis }\end{array}$ & $\begin{array}{l}\text { Nitto NTR 7430, } \\
\mathrm{CO}=1 \mathrm{kDa}\end{array}$ & $\begin{array}{l}\text { Reduction of } \\
\text { xylose to xylitol }\end{array}$ & $\begin{array}{l}\text { Production of } \\
\text { xylitol, a natural } \\
\text { food sweetener }\end{array}$ & $\begin{array}{l}\text { Nidetzky et al. } \\
\text { [48] }\end{array}$ \\
\hline $\begin{array}{l}\text { chitosanases } \\
\text { and chitinase } \\
\text { from Bacillus } \\
\text { cereus }\end{array}$ & $\begin{array}{l}\text { Amicon Diaflo }{ }^{\circledR} \\
\mathrm{H} 1510-43, \\
\mathrm{CO}=10 \mathrm{kDa}\end{array}$ & $\begin{array}{l}\text { Hydrolysis of } \\
\text { chitosan }\end{array}$ & $\begin{array}{l}\text { Production } \\
\text { of chitooligo- } \\
\text { saccharides }\end{array}$ & Kuo et al. [49] \\
\hline $\begin{array}{l}\text { Pronase from } \\
\text { Streptomyces } \\
\text { griseus }\end{array}$ & $\begin{array}{l}\text { Amicon } \\
\text { Diaflo }{ }^{\circledR} \mathrm{H} 1510 \text {, } \\
\mathrm{CO}=10 \mathrm{kDa}\end{array}$ & $\begin{array}{l}\text { Hydrolysis of soy } \\
\text { protein isolate }\end{array}$ & $\begin{array}{l}\text { Production } \\
\text { of soy protein } \\
\text { hydrolysates for } \\
\text { functional food }\end{array}$ & $\begin{array}{l}\text { Deeslie and } \\
\text { Cheryan [50] }\end{array}$ \\
\hline
\end{tabular}


Tab. 2.4: Examples of applications of membrane reactors to the wastewater treatment.

\begin{tabular}{|c|c|c|c|c|c|}
\hline Enzyme & Source & Reactor & Membrane & Application & Reference \\
\hline \multicolumn{6}{|c|}{ Immobilized enzyme membrane reactor } \\
\hline $\begin{array}{l}\text { Crude en- } \\
\text { zyme extract }\end{array}$ & $\begin{array}{l}\text { Pseudo- } \\
\text { monas sp. }\end{array}$ & Batch UF cell & $\begin{array}{l}\text { Flat poly- } \\
\text { acrylonitrile }\end{array}$ & $\begin{array}{l}\text { Phenolic } \\
\text { effluent }\end{array}$ & $\begin{array}{l}\text { Bohdziewicz } \\
\text { [8], Bodzek } \\
{[52]}\end{array}$ \\
\hline $\begin{array}{l}\text { Polyphenol } \\
\text { oxidase } \\
\text { (EC 1.14.18.1) }\end{array}$ & $\begin{array}{l}\text { Agaricus } \\
\text { bisporum }\end{array}$ & $\begin{array}{l}\text { Hollow fiber } \\
\text { membrane } \\
\text { reactor }\end{array}$ & Polysulphone & $\begin{array}{l}\text { Coal-gas con- } \\
\text { version plant } \\
\text { effluents } \\
\text { (phenols) }\end{array}$ & $\begin{array}{l}\text { Edwards } \\
\text { et al. [53] }\end{array}$ \\
\hline $\begin{array}{l}\text { Laccasse } \\
(\text { EC 1.10.3.2) }\end{array}$ & $\begin{array}{l}\text { Pyricularia } \\
\text { oryzae }\end{array}$ & $\begin{array}{l}\text { Spiral-wound } \\
\text { module }\end{array}$ & $\begin{array}{l}\text { Polyether- } \\
\text { sulphone }\end{array}$ & $\begin{array}{l}\text { Synthetic } \\
\text { industrial } \\
\text { wastewater } \\
\text { (phenols) }\end{array}$ & $\begin{array}{l}\text { Lante et al. } \\
\text { [54] }\end{array}$ \\
\hline Laccasse & $\begin{array}{l}\text { Trametes } \\
\text { versicolor }\end{array}$ & $\begin{array}{l}\text { Frame plate } \\
\text { reactor mod- } \\
\text { ule }\end{array}$ & $\begin{array}{l}\text { Modified } \\
\text { polyvinyl- } \\
\text { idene di- } \\
\text { fluoride } \\
\text { (PVDF) }\end{array}$ & $\begin{array}{l}\text { Herbicide } \\
N^{\prime}, N^{\prime} \text { - } \\
\text { (dimethyl)- } \\
N \text {-(2-hydroxy- } \\
\text { phenyl) urea } \\
(2-\mathrm{HF})\end{array}$ & $\begin{array}{l}\text { Jolivalt et al. } \\
\text { [55] }\end{array}$ \\
\hline \multicolumn{6}{|c|}{ Extractive membrane bioreactor } \\
\hline $\begin{array}{l}\text { Glucose } \\
\text { oxidase }\end{array}$ & $\begin{array}{l}\text { Aspergilus } \\
\text { Niger }\end{array}$ & Hollow fiber & $\begin{array}{l}\text { Polyether- } \\
\text { sulphone }\end{array}$ & $\begin{array}{l}\text { Synthetic } \\
\text { industrial } \\
\text { wastewater } \\
\text { (glucose) }\end{array}$ & $\begin{array}{l}\text { Kojima et al. } \\
\text { [56] }\end{array}$ \\
\hline $\begin{array}{l}\text { Glycerol } \\
\text { dehydro- } \\
\text { genase }\end{array}$ & $\begin{array}{l}\text { Enterobacter } \\
\text { aerogenes }\end{array}$ & $\begin{array}{l}\text { Stirred tank } \\
\text { reactor and } \\
\text { hollow fiber }\end{array}$ & $\begin{array}{l}\text { Polyether- } \\
\text { sulphone and } \\
\text { hydrophobic } \\
\text { membrane }\end{array}$ & $\begin{array}{l}\text { Ethanol oxi- } \\
\text { dation }\end{array}$ & $\begin{array}{l}\text { Liese et al. } \\
{[57]}\end{array}$ \\
\hline \multicolumn{6}{|c|}{ Membrane separation reactor } \\
\hline $\begin{array}{l}\text { Soybean } \\
\text { peroxidase }\end{array}$ & $\begin{array}{l}\text { Ground } \\
\text { soybean } \\
\text { seed-hulls }\end{array}$ & $\begin{array}{l}\text { Stirred tank } \\
\text { reactor }\end{array}$ & - & $\begin{array}{l}\text { Synthetic } \\
\text { industrial } \\
\text { wastewater } \\
\text { (phenols) }\end{array}$ & $\begin{array}{l}\text { Flock et al. } \\
\text { [58] }\end{array}$ \\
\hline Pectolyase & $\begin{array}{l}\text { Aspergilus } \\
\text { japonicus }\end{array}$ & $\begin{array}{l}\text { Stirred tank } \\
\text { reactor }\end{array}$ & $\begin{array}{l}\text { Polyether- } \\
\text { sulphone }\end{array}$ & $\begin{array}{l}\text { Depoly- } \\
\text { merization } \\
\text { of polygalac- } \\
\text { turonic acid }\end{array}$ & $\begin{array}{l}\text { Gallifuoco } \\
\text { et al. [59] }\end{array}$ \\
\hline $\begin{array}{l}\text { Manganese } \\
\text { peroxidase }\end{array}$ & $\begin{array}{l}\text { Bjerkandera } \\
\text { sp. }\end{array}$ & $\begin{array}{l}\text { Stirred tank } \\
\text { reactor }\end{array}$ & $\begin{array}{l}\text { Polyether- } \\
\text { sulphone }\end{array}$ & $\begin{array}{l}\text { Dye decol- } \\
\text { orization }\end{array}$ & $\begin{array}{l}\text { López et al. } \\
\text { [20] }\end{array}$ \\
\hline
\end{tabular}




\subsection{Membrane aeration bioreactors (MABR)}

A basic requirement for the aerobic degradation of organic material is oxygen, which is required to support the life and growth of the microbes performing the degradation. It is therefore imperative that these systems receive sufficient oxygen as, without it, a rapid deterioration in the quality of effluent will occur [62]. The rate of oxygen mass transfer can be greatly improved by using high purity oxygen rather than atmospheric air (approximately by a factor of 5), but these oxygenation devices require a great deal of power in order to efficiently mix the gas into the solution and obtain a high oxygen transfer efficiency; they thus cannot be used in conjunction with biofilm processes in which the reactor should remain static [20]. The membrane aeration bioreactor (MABR) concept was developed in response to the need for increased oxygen mass transfer into wastewaters in cases where the oxygen requirements for degradation of the pollutant were too high for conventional aeration processes. It is also applicable when the bubbling of air can result in either stripping of volatile organic compounds (VOCs) [63], foaming [17] of industrial wastewaters or the damage to shear-sensitive cell cultures [64]. The membrane itself can play a dual role in the reactor, namely as a means for supplying oxygen and a substrate for biofilm formation.

Fig. 2.7 is a schematic diagram outlining the principle of the MABR. A membrane (dense gas permeable, microporous or composite, i.e. microporous coated with a nonporous gas permeable) is used to transfer oxygen to the bacteria present in the bioreactor without forming bubbles and with $100 \%$ oxygen transfer efficiency. The membrane also acts as a support for biofilm growth. Wastewater flows over the outer surface of the biofilm and counter-diffusion of oxygen and pollutant occurs, as shown in Fig. 2.7 (a). Oxygen transferred through the membrane is utilized in the degradation of pollutants in the biofilm. MABRs have been use to treat a wide variety of wastewater types and have been shown to be particularly effective in treating high oxygen demanding wastewaters [65], biodegradation of VOCs [66, 67], combined nitrification, denitrification and/or organic carbon degradation in a single biofilm $[68,69]$. When a MABR system is used for the treatment of waste vapor streams, volatile organic compounds (VOCs) and oxygen are transferred concurrently through the membrane to the biofilm and a liquid phase flowing on the opposite side of the membrane is a source of mineral salts for the culture growth. The most commonly used membranes for MABRs are silicon rubber tubing [70] and microporous polypropylene hollow fiber membranes [67]. For the biotreatment of vapor streams containing aromatic contaminants, the nonporous silicone membrane system delivered superior performance over the microporous membrane system in terms of surface-area-based removal rates, long-term operational stability and maintenance [67]. 


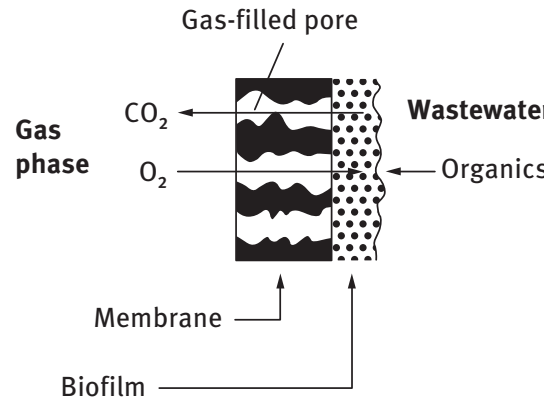

(a)

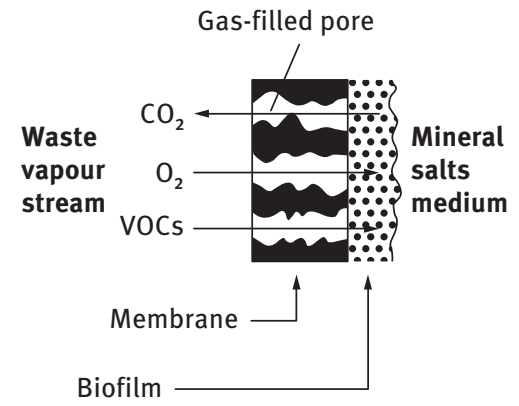

(b)

Fig. 2.7: Schematic diagram of the MABR system utilizing a hydrophobic microporous membrane: (a) biodegradation of organics from a wastewater stream; (b) removal of VOCs from a waste vapor stream.

\subsection{Extractive membrane bioreactors (EMBR)}

\subsubsection{Concept}

The principle of an EMBR is illustrated in Fig. 2.8. An aqueous feed stream (usually wastewater) containing the organic compound(s) to be degraded is passed over one surface of a nonporous semipermeable membrane, while a biocatalyst (usually microbial culture) is maintained in an oxygenated aqueous biomedium at the other surface. The $\mathrm{pH}$ and ionic strength of the wastewater have no influence on the makeup of the biomedium as the membrane is impermeable to any inorganic or charged species in the wastewater. Thus the biomedium composition can be controlled and optimized independently of the composition of the wastewater to provide optimal growth conditions for the microbial culture in spite of the biologically hostile makeup of the wastewater [71]. The driving force for the mass transfer across the membrane is the

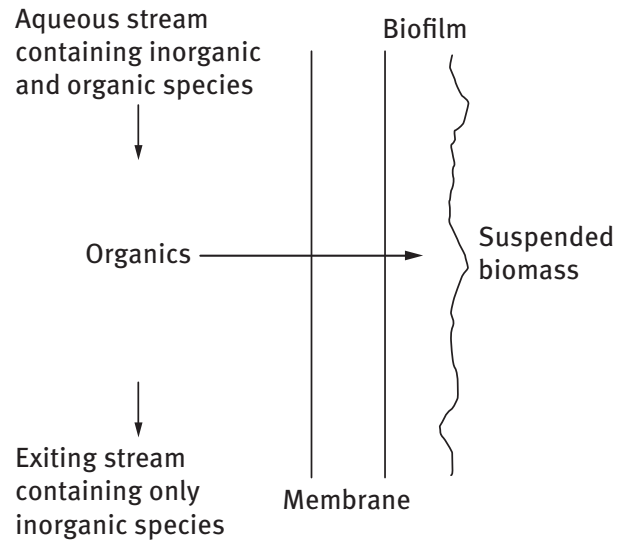

Fig. 2.8: Schematic diagram of the EMBR process. Organic pollutants selectively diffuse through the nonporous membrane material into the biomedium phase where they are biodegraded in the biofilm. 
concentration difference between the organic pollutant in the wastewater and in the biomedium, which is maintained by biological degradation.

The EMBR systems are usually composed of silicone rubber (polydimethylsiloxane) tubing or plates. The pilot unit, schematically represented in Fig. 2.9, consists of two membrane modules, each with eight coils of silicone tubing linked in series and submerged in a reactor fitted with a mechanical stirrer. Wastewater was fed through the membrane tubes. Air was bubbled through the reactor to maintain the dissolved oxygen concentration at the optimum level. Low pressure steam was fed directly into the reactor tank to maintain temperature at around $30^{\circ} \mathrm{C}$. $\mathrm{pH}$ was controlled by the automatic dosing of either sulphuric acid or sodium hydroxide solution.

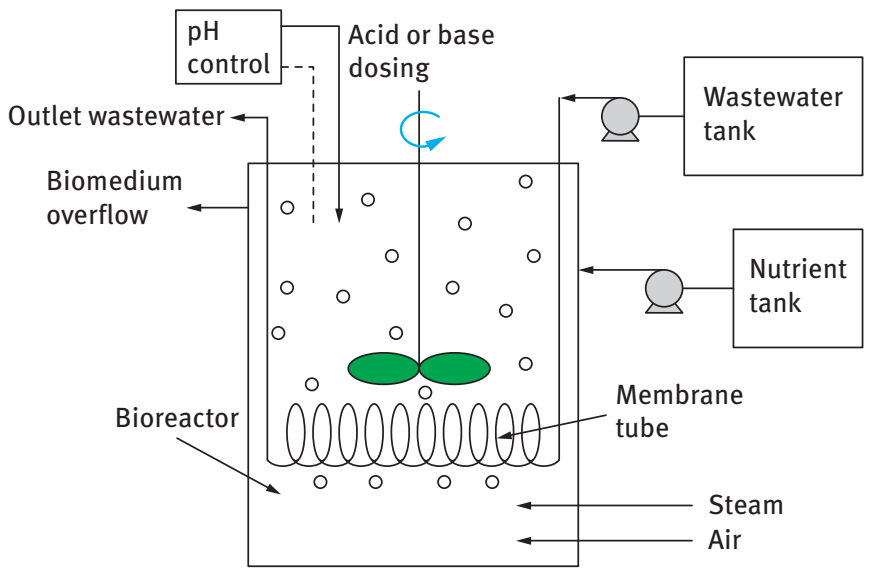

Fig. 2.9: Schematic diagram of the pilot-scale EMBR unit [18].

Due to bacterial attachment, a membrane-attached biofilm forms on the shell side of the membrane. A thin biofilm $(200-400 \mu \mathrm{m})$ is advantageous because it limits the air stripping of volatile organic compounds [72]. However, an increase in biofilm thickness results in a decrease in organic pollutant(s) flux across the membrane. The EMBR shares this problem with membrane aeration reactors, where membraneattached biofilms also create mass transfer limitations [73, 74]. It was confirmed by mathematical modeling of biofilm growth in an EMBR that due to the limited solubility of oxygen in water, oxygen could only penetrate thin biofilms [75]. Therefore, the active layer is very close to the biofilm/biomedium interface. Consequently, an inverse relationship between the organic flux and biofilm thickness was observed. Several modifications have been attempted to suppress the metabolism of the biofilmforming bacteria, such as addition of sodium chloride [76], increasing the shear stress on the membrane surface [77], using a biphasic system [78] and the addition of nitrate as an electron acceptor instead of oxygen [79]. Nitrate is highly soluble in water and therefore, the nitrate concentration in the biomedium can be sufficiently high to fully 
penetrate the biofilm, ensuring that nitrate is present at the biofilm/membrane interface. Theoretically, the substrate could then be biodegraded at the biofilm/membrane interface, alleviating the decrease in pollutant flux with biofilm growth. Another approach is based on the modification of the interfacial properties that regulate microbial attachment to the membrane through addition of surfactants [80].

\subsubsection{Application}

EMBR was used for degradation of organic pollutants and solvents from synthetic and industrial wastewaters. More than $99 \%$ of 1,2-dichloroethane (1,2-DCA) was removed from a synthetic wastewater containing $1600 \mathrm{mg} \mathrm{l}^{-1}$ of 1,2-DCA [63]. 2,4-dichlorophenoxyacetic acid, a component of commercial herbicides, has also been successfully degraded at laboratory scale using a suitably acclimated microbial culture [81]. In addition, toluene and dichloromethane, the two most commonly used solvents in the chemical and pharmaceutical industries, were being degraded by a commensal microbial culture [82].

When EMBR was used with industrial wastewaters, the results were also encouraging. Wastewater from a 3-chloronitrobenzene-manufacture plant was successfully remediated with the removal efficiencies of greater than $99 \%$ at residence times of $\sim 30 \mathrm{~min}$ [83]. Brookes and Livingston [84, 85] operated a laboratory-scale reactor continuously for 5 months and consistently removed aniline, 4-chloroaniline, 2,3-dichloroaniline and 3,4-dichloroaniline at efficiencies greater than 99\%. Conventional direct biological treatment of such effluents cannot be implemented without pretreatment or dilution because of the hostile inorganic composition of the wastewater. Other examples of successful application include the removal and degradation of compounds such as monochlorobenzene, where 98 to $99 \%$ of the pollutant was destroyed at a flow rate of $50 \mathrm{l} / \mathrm{h}$ [71], 1,2-dichloroethane (94.5\% removal) with negligible air stripping [63] and various other chemical and pharmaceutical waste streams with similar results. Particularly, the EMBR system is suitable for the treatment of wastewaters in which a recalcitrant hydrophobic toxic compound is mixed with high concentrations of an easily biodegradable hydrophilic compound. Biodegradation of such wastewaters is difficult in conventional bioreactors, since the microbial cultures tend to grow on the easily biodegradable compound in preference to the toxic compounds. An example of this type of wastewater is the industrial wastewater produced from a hydrogenation process that contains $\mathrm{g} \mathrm{l}^{-1}$ concentrations of toluidines such as 3-chloro-4-methylaniline and methylammines (which are hydrophobic and not Note 7: Misseasily biodegradable) and up to $2-3 \mathrm{vol} \%$ of methanol (which is hydrophilic and easily biodegradable) [18]. The EMBR technology is suitable for treating this kind of waste, since the hydrophobic target compounds can rapidly cross the membrane and be degraded in the bioreactor, whilst the hydrophilic methanol is retained in the EMBR effluent and goes on to further treatment. 
A number of variations of the basic EMBR configuration have been attempted. Splendiani et al. [78] have developed the biphasic extractive membrane bioreactor (BEMBR) in which biofilm accumulation was controlled by preventing direct contact between microorganisms and the membrane. In BEMBR systems, the two main constituents of the process, membrane and bacteria, are kept separated and interact via a suitable recirculating solvent, as shown in Fig. 2.10. The BEMBR system consists of a biphasic bioreactor and a membrane module with a silicone rubber tube fitted coaxially in a cylindrical shell. The nonporous membrane selectively extracts the organic pollutants from the waste streams. On the shell side, the pollutants are desorbed into the organic solvent, which is re-circulated between the membrane module and the bioreactor. In the bioreactor, the pollutant-rich solvent is mixed with the aqueous biomedium, and the pollutants are transferred from the solvent to the aqueous biomedium where they are metabolized by suspended bacteria. The lean solvent is continuously separated from the aqueous biomedium and recycled back into the membrane shell. The organic solvent must not be toxic for bacteria or inhibit the pollutant metabolization; it must not be utilized by bacteria as a source of carbon and energy - it must exhibit low microbial adhesivity, low membrane swelling and emulsionforming tendency. According to Splendiani et al. [78], the solvent that best satisfies these requirements is perfluoromethyldecalin (PFMD). They tested the BEMBR system with PFMD as a solvent for degradation of monochlorobenzene using a synthetic wastewater. The system was operated over a one-month period with negligible biofilm accumulation. Throughout the period of operation, the overall mass transfer coefficient remained stable at approximately the value obtained for mass transfer through the bare membrane.

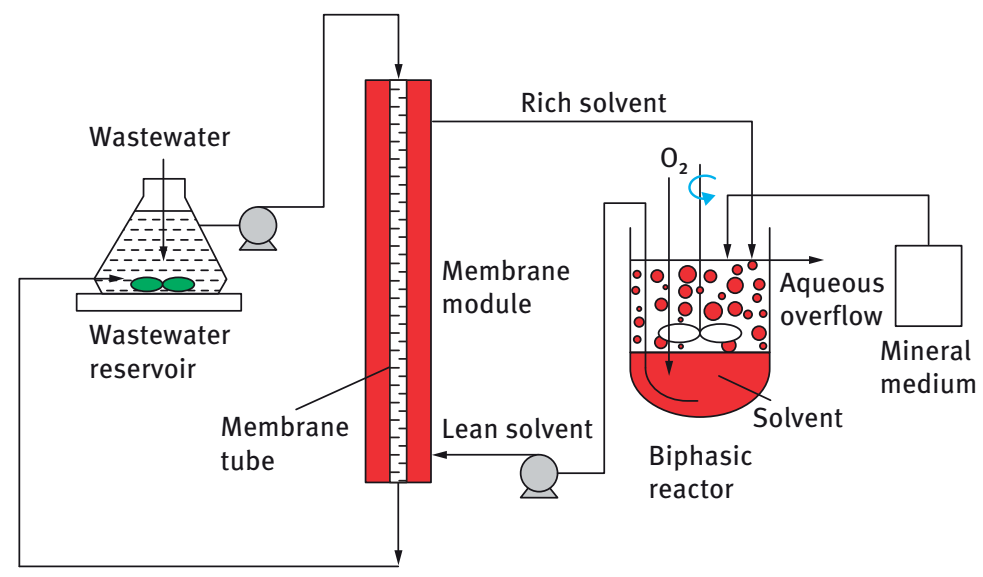

Fig. 2.10: Schematic diagram of the biphasic EMBR process [78]. 
Liu et al. $[86,87]$ coupled EMBR with the conventional solvent extraction and stripping to degrade chlorophenolic compounds to levels lower than $100 \mathrm{mg} \mathrm{l}^{-1}$. The process was operated in four units shown in Fig. 2.11: (1) Extraction unit. The acidic organic pollutant in the acidic wastewater (stream $a$, containing $1000 \mathrm{mg} \mathrm{l}^{-1}$ 2,4-dichlorophenol (DCP), and $5 \% \mathrm{NaCl}$ at $\mathrm{pH}<1$ ) is extracted by a water insoluble organic solvent. The raffinate is discharged after filtering through a hydrophilic microfiltration membrane that minimizes loss of organics in droplet form (stream $b$, containing $<100 \mathrm{mg} \mathrm{l}^{-1} \mathrm{DCP}$ and $5 \% \mathrm{NaCl}$ at $\mathrm{pH}<1$ ). (2) Stripping unit. The extract is pumped from the extraction unit to the stripping unit where organic pollutant is transferred into an alkaline aqueous phase and its concentration in the raffinate out of the stripping unit (stream $c$ ) is much higher than that in the treated water (stream $b$ ). (3) Membrane separation of $O / W$ emulsion and biomass. Organic droplets in the raffinate from the stripping unit (stream $c$ ) are filtered out by the hydrophilic ceramic membrane, thus the organic pollutant is fed into the bioreactor but not the solvent droplets. The outlet stream of the bioreactor is filtered from the reverse direction in a second membrane for the purpose of removing the reaction products while retaining the biocatalysts. These units are periodically switched in function. After the switch the filtration of biomass separation serves to backflush the membrane previously used for filtering the $\mathrm{O} / \mathrm{W}$ emulsion and vice versa. In this way, membrane fouling is reduced. (4) Bioreactor. The organic pollutant is fed to the bioreactor as the carbon and energy source for the bacteria and may be supplied to be present at optimum concentrations and suitable $\mathrm{pH}$ and temperature. When the pollutants are chlorinated hydrocarbons, hydrochloric acid is released as the biodegradation by-product. The hydroxide ion present in the stripping solution is consumed to neutralize the hydrochloric acid.

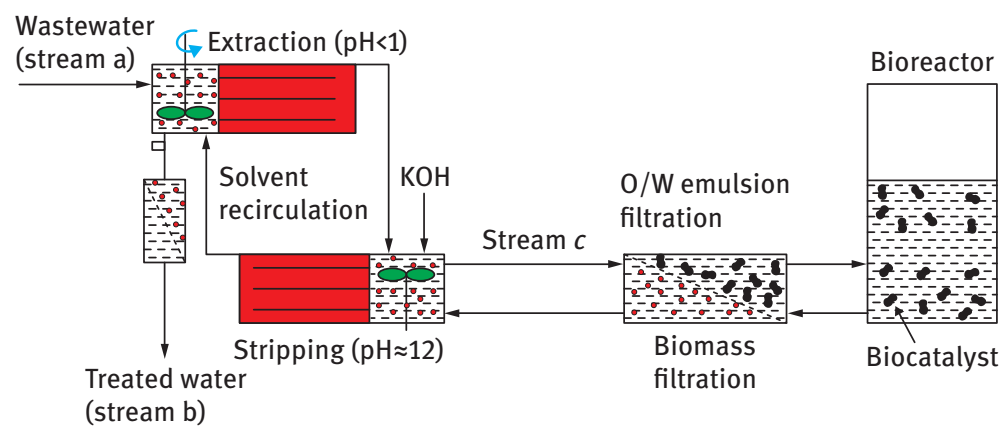

Fig. 2.11: Schematic diagram of the hybrid EMBR process, combining conventional liquid-liquid extraction cycle and a membrane bioreactor $[86,87]$. 


\subsection{Enzyme immobilization techniques in membrane reactor systems}

Immobilization is a very powerful tool to improve almost all properties of biocatalysts (enzymes and whole cells) such as stability, activity, specificity and selectivity [88]. Immobilization also simplifies the separation of reaction products from catalysts and facilitates the recovery and reuse of catalysts, which frequently is too expensive for one-time use. Many approaches exist for the immobilization of enzymes in microporous membranes, as illustrated in Fig. 2.12. Enzymes can be covalently bound or cross-linked within porous membranes, attached to a membrane surface by physical adsorption or ionic binding, entrapped within the porous substructure of asymmetric membranes, encapsulated in microporous beads or particles and segregated (localized) between two sets of hollow fiber membrane or two sheets of flat membrane [89]. The examples of enzyme immobilization techniques in membrane reactors are listed in Tab.2.5.

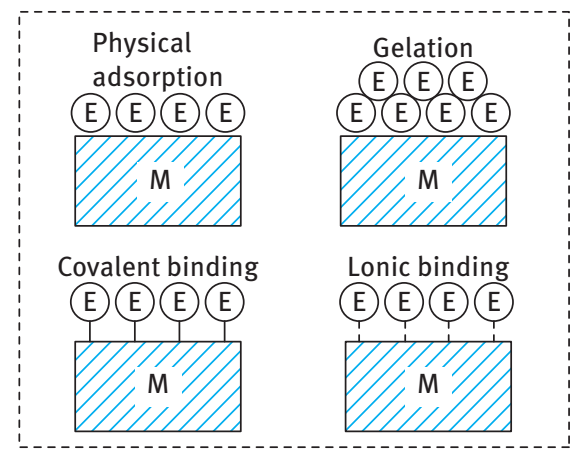

(a) Attachment to membrane

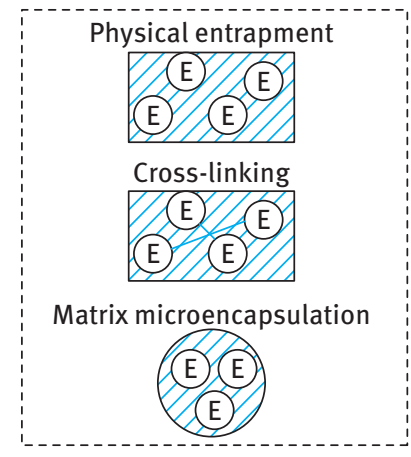

(b) Matrix entrapment

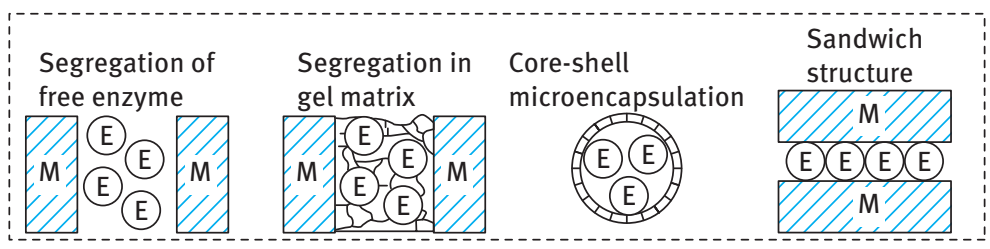

(c) Separation by membranes

Fig. 2.12: Schematic representations of enzyme immobilization techniques in membrane reactors, where $M=$ membrane and $E=$ enzyme. 
Tab. 2.5: Examples of enzyme immobilization techniques in membrane reactors (CO = cut-off).

\begin{tabular}{|c|c|c|c|c|c|}
\hline Enzyme & Membrane & Reaction & $\begin{array}{l}\text { Immobilization } \\
\text { method }\end{array}$ & Reactor & Reference \\
\hline $\begin{array}{l}\text { Pig liver es- } \\
\text { terase }\end{array}$ & $\begin{array}{l}\text { polyamide } \\
\text { hollow fibers }\end{array}$ & $\begin{array}{l}\text { Stereo- } \\
\text { selective } \\
\text { hydrolysis } \\
\text { of cis-DE }\end{array}$ & $\begin{array}{l}\text { Covalent bind- } \\
\text { ing, physical } \\
\text { entrapment }\end{array}$ & Multiphase & $\begin{array}{l}\text { Sousa et al. } \\
\text { [12] }\end{array}$ \\
\hline $\begin{array}{l}\text { lipase from } \\
\text { Pseudomonas }\end{array}$ & $\begin{array}{l}\text { Polyamide } \\
\text { hollow fibers }\end{array}$ & $\begin{array}{l}\text { Stereo- } \\
\text { selective } \\
\text { hydrolysis } \\
\text { of 1-PEA }\end{array}$ & $\begin{array}{l}\text { Covalent bind- } \\
\text { ing }\end{array}$ & Multiphase & $\begin{array}{l}\text { Ceynowa and } \\
\text { Koter [90] }\end{array}$ \\
\hline $\begin{array}{l}\text { lipase from } \\
\text { Candida cylin- } \\
\text { dracea }\end{array}$ & $\begin{array}{l}\text { PAN hollow } \\
\text { fibers }\end{array}$ & $\begin{array}{l}\text { Stereo- } \\
\text { selective } \\
\text { hydrolysis } \\
\text { of MMPG }\end{array}$ & $\begin{array}{l}\text { Physical en- } \\
\text { trapment }\end{array}$ & Multiphase & $\begin{array}{l}\text { Lopez et al. } \\
\text { [91] }\end{array}$ \\
\hline $\begin{array}{l}\text { lipase from } \\
\text { Candida } \\
\text { rugosa or } \\
\text { Pseudomonas } \\
\text { cepacia }\end{array}$ & $\begin{array}{l}\text { PAN and PES } \\
\text { hollow fibers }\end{array}$ & $\begin{array}{l}\text { Stereo- } \\
\text { selective } \\
\text { hydrolysis } \\
\text { of naproxen } \\
\text { methyl ester }\end{array}$ & $\begin{array}{l}\text { Physical en- } \\
\text { trapment }\end{array}$ & Multiphase & $\begin{array}{l}\text { Sakaki et al. } \\
{[16]}\end{array}$ \\
\hline $\begin{array}{l}\text { bovine liver } \\
\text { catalyse }\end{array}$ & $\begin{array}{l}\text { Cellulose } \\
\text { acetate hollow } \\
\text { fibers }\end{array}$ & $\begin{array}{l}\text { blood oxygena- } \\
\text { tion }\end{array}$ & $\begin{array}{l}\text { Covalent bind- } \\
\text { ing }\end{array}$ & MSR & Cioci et al. [92] \\
\hline $\begin{array}{l}\text { Fructosime L } \\
\text { (inulinases } \\
\text { from Asper- } \\
\text { gillus niger) }\end{array}$ & $\begin{array}{l}\text { PS hollow } \\
\text { fibers }\end{array}$ & $\begin{array}{l}\text { Hydrolysis of } \\
\text { inulin }\end{array}$ & $\begin{array}{l}\text { Physical ad- } \\
\text { sorption }\end{array}$ & MSR & Díaz et al. [93] \\
\hline $\begin{array}{l}\text { Lipase from } \\
\text { Candida cylin- } \\
\text { dracea }\end{array}$ & $\begin{array}{l}\text { PP hollow } \\
\text { fibers }\end{array}$ & $\begin{array}{l}\text { Hydrolysis of } \\
\text { olive oil }\end{array}$ & $\begin{array}{l}\text { Physical ad- } \\
\text { sorption }\end{array}$ & Multiphase & Hoq et al. [94] \\
\hline $\begin{array}{l}\text { Cellulase from } \\
\text { Humicola } \\
\text { insolens }\end{array}$ & $\begin{array}{l}\text { Polymer- } \\
\text { coated ceramic } \\
\text { membrane }\end{array}$ & $\begin{array}{l}\text { Hydrolysis of } \\
\text { carboxy-methyl } \\
\text { cellulose }\end{array}$ & $\begin{array}{l}\text { Covalent bind- } \\
\text { ing }\end{array}$ & $\begin{array}{l}\text { High-pressure } \\
\text { with } \mathrm{SC} \mathrm{CO}_{2}\end{array}$ & $\begin{array}{l}\text { Habulin et al. } \\
\text { [23] }\end{array}$ \\
\hline $\begin{array}{l}\text { fructosyl- } \\
\text { transferase of } \\
\text { Streptococcus } \\
\text { mutans }\end{array}$ & $\begin{array}{l}\text { Nanoparticle } \\
\text { composite PET } \\
\text { membrane }\end{array}$ & $\begin{array}{l}\text { Synthesis of } \\
\text { poly- } \beta-(2-1)- \\
\text { fructan (inulin) }\end{array}$ & $\begin{array}{l}\text { Covalent bind- } \\
\text { ing }\end{array}$ & MSR & $\begin{array}{l}\text { Hicke et al. } \\
{[95]}\end{array}$ \\
\hline $\begin{array}{l}\text { Chymotrypsin, } \\
\alpha \text {-amylase, } \\
\text { thermo- } \\
\text { amylase, } \\
\text { amino-acid } \\
\text { ester hydro- } \\
\text { lase }\end{array}$ & $\begin{array}{l}\text { Silica modified } \\
\text { PVC membrane }\end{array}$ & $\begin{array}{l}\text { Hydrolysis } \\
\text { of DL-Trypto- } \\
\text { phane methyl } \\
\text { ester, starch, } \\
\text { and DL-pheGly } \\
\text { methyl ester }\end{array}$ & $\begin{array}{l}\text { Physical en- } \\
\text { trapment } \\
\text { followed by } \\
\text { cross linking } \\
\text { the enzyme }\end{array}$ & MSR & Simon [13] \\
\hline $\begin{array}{l}\text { Lipase from } \\
\text { Candida ru- } \\
\text { gosa }\end{array}$ & $\begin{array}{l}\text { Hydrophilic } \\
\text { PAN mem- } \\
\text { brane, } \\
\mathrm{CO}=50 \mathrm{kDa}\end{array}$ & $\begin{array}{l}\text { Stereo- } \\
\text { selective } \\
\text { hydrolysis } \\
\text { of ibuprofen } \\
\text { methyl ester }\end{array}$ & $\begin{array}{l}\text { Physical en- } \\
\text { trapment }\end{array}$ & Multiphase & Long et al. [96] \\
\hline
\end{tabular}




\subsubsection{Physical adsorption}

The method relies on non-specific physical interaction between the enzyme protein and the surface of the membrane, brought about by mixing a concentrated solution of enzyme over the membrane in stirred cells or by recirculating a concentration solution along the membrane. A major advantage of adsorption as a method of immobilizing enzymes is that usually no reagents and only a minimum of activation steps are required. As a result, adsorption is cheap, easily carried out, and tends to be less disruptive to the enzymic protein than chemical means of attachment, the binding being mainly performed by hydrogen bonds, multiple salt linkages and Van der Waal's forces. In this respect, the method bears the greatest similarity to the situation found in biological membranes in vivo and has been used to model such systems. Because of the weak bonds involved, desorption of the protein resulting from changes in temperature, $\mathrm{pH}$, ionic strength or even the mere presence of substrate, is often observed. Another disadvantage is non-specific further adsorption of other substances as the immobilized enzyme is used. This may alter the properties of the immobilized enzyme or, if the substance adsorbed is a substrate for the enzyme, the rate will probably decrease depending on the surface mobility of enzyme and substrate. Adsorption of the enzyme may be necessary to facilitate the covalent reactions described later. Stabilization of enzymes temporarily adsorbed onto a membrane matrix has been achieved by crosslinking the protein in a chemical reaction subsequent to its physical adsorption.

\subsubsection{Entrapment}

Matson [97] has developed an enzyme immobilization technique in which the enzyme is contained in an asymmetric or composite membrane between two immiscible liquid streams. This type of immobilization is common in multiphase hollow-fiber reactors described in details in Section 2.8. Initially, an aqueous enzyme solution is charged to the shell (or outer) side of the hollow-fiber module and passed though the fiber wall under a modest pressure difference (i.e. a pressure insufficient to cause disruption or loss of integrity of the skin under "back-flush" conditions). During this step, enzyme is accumulated in the porous substrate region of the fiber. Next, excess aqueous enzyme solution is displaced from the shell side of the fiber bundle by flushing it with an immiscible fluid such as air or the organic solvent. The module is then operated with the organic solvent on the shell side and an aqueous solution in the lumen of the fiber with a slight excess pressure on the shell side. When the enzyme becomes deactivated and must be recharged, a positive pressure is applied to the aqueous solution on the interior or lumen side of the fibers, thereby causing convective flow through the membrane and displacement both of organic solvent from the shell side of the module as well as deactivated enzyme from the fiber walls. 


\subsubsection{Cross linking}

Immobilization of enzymes has been achieved by intermolecular cross-linking of the protein, either to other protein molecules or to functional groups on a membrane matrix. Cross-linking an enzyme to itself is both expensive and insufficient, as some of the protein material will inevitably be acting mainly as a support, resulting in relatively low enzymic activity. Generally, cross-linking is best used in conjunction with one of the other methods. For instance, enzyme may first be adsorbed on membrane exterior or pore wall surfaces, subsequently to be anchored more positively by crosslinking the adsorbed enzyme layer in place. Or, enzyme may first be encapsulated in polyacrylamide microgels and then cross-linked with glutaraldehyde to prevent leakage out of the large pores in gel matrix.

\subsubsection{Encapsulation}

Since the second half of the $20^{\text {th }}$ century, numerous efforts have been devoted to the development of enzyme microencapsulation techniques for various applications. The examples of novel functional micro/nano-particles used for the microencapsulation of enzymes can be seen in Fig. 2.13. In particular, membrane and microfludic devices are considered to be very efficient tools for the production of size-controlled enzymeloaded emulsion droplets. Solid microparticles can be produced by secondary reactions in the emulsified droplets, such as colloidal or molecular self-assembly, polymerization, gelation, and crystallization [98]. In the next sections the use of microfluidic devices in the precise manufacture of enzyme-loaded microcapsules is explained in more details.

\subsubsection{Asymmetric vesicles}

Pautot et al. [99] fabricated asymmetric vesicles, where the inner leaflet was composed of POPC (1-palmitoyl-2-oleoyl-sn-glycero-3-phosphocholine) and the outer leaflet composed of POPS (1-palmitoyl-2-oleoyl-sn-glycero-3-phospho-L-serine), or the reverse. The flow focusing microfluidic device (FFMD) shown in Fig. 2.14 generates enzymeloaded triple emulsions in a single step [100]. The device consists of two concentric tapered tubes nested within an outer square tube. The innermost fluid comprising of aqueous solution of enzymes is pumped through the inner injection tube, the middle fluid $\mathbf{2}$ pumped through the outer injection tube, and the middle fluid $\mathbf{1}$ flows through the square tube outside the injection tubes. The outermost fluid is pumped through the square tube from the opposite direction, and all fluids are forced through the exit orifice formed at the entrance of the 'collection tube'. This geometry results in hydrodynamic focusing and rupturing of three coaxial jets, followed by the formation of triple emulsion droplets containing enzyme solution surrounding by two phos- 


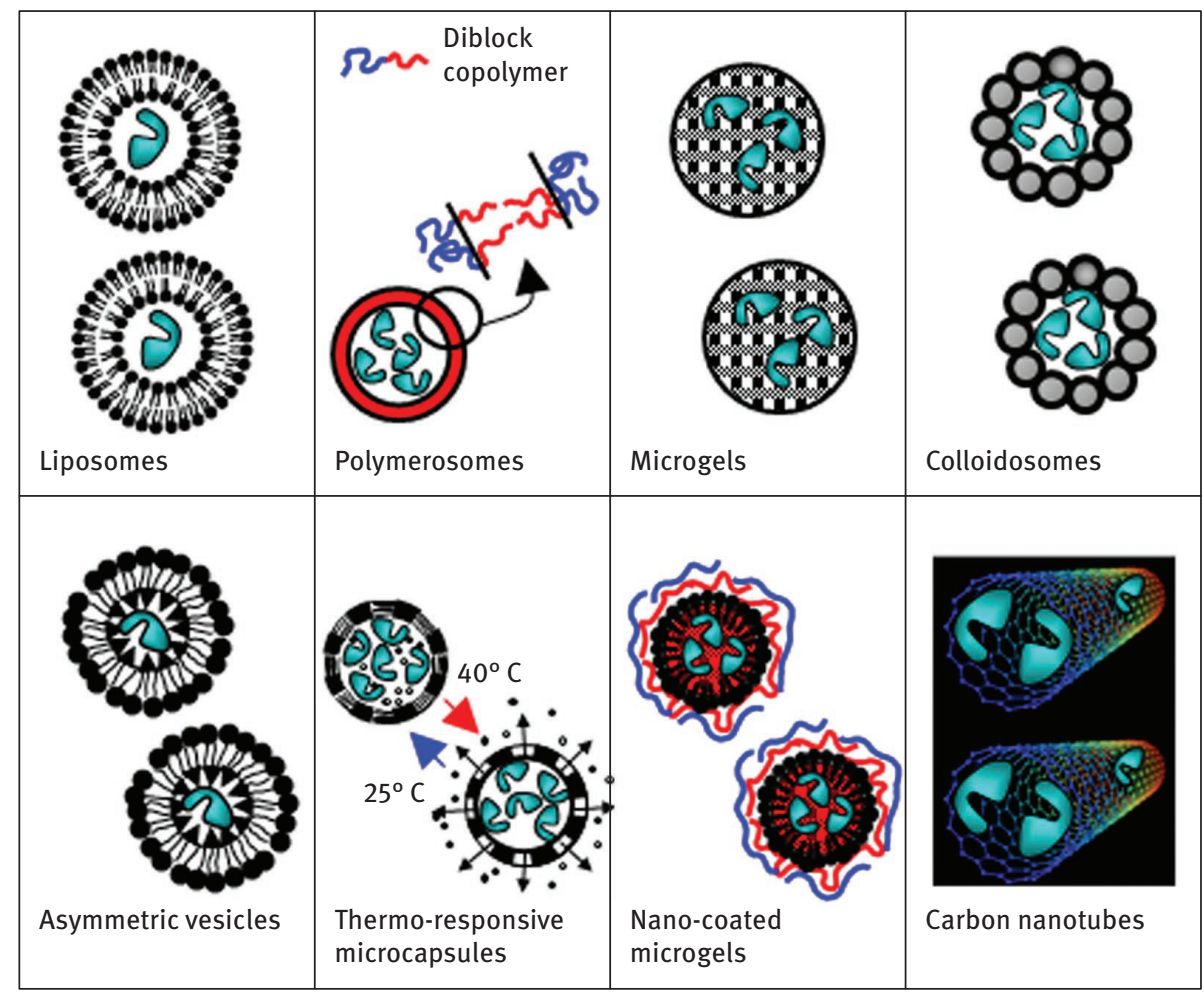

Fig. 2.13: Examples of enzyme microcapsules.

pholipid shells. The volume of each phase can be tuned by changing the fluid flow rates. Typical diameters of the exit orifice range from 20 to $200 \mu \mathrm{m}$, which allows the drop size to be adjusted over a wide range. This triple emulsion is a template to prepare asymmetric enzyme-loaded vesicle with two layers consisting of amphiphilic molecules of different chemical structure.

\subsubsection{Polymerosomes}

The use of diblock copolymers to generate vesicles is an attractive strategy to create new structures for enzyme encapsulation called polymerosomes, by analogy with more traditional liposomes. The flexibility afforded by the use of diblock copolymers significantly increases the control over the properties of polymerosomes. For example, the membrane thickness can be controlled by varying the degree of polymerization of the individual diblock molecules, whereas fluidity and permeability of the membrane can be adjusted by changing the glass transition temperature of the hydrophobic block. Similarly, control over the nature of the individual polymer blocks can lead to alternative mechanisms to trigger substrate loading and product release. 

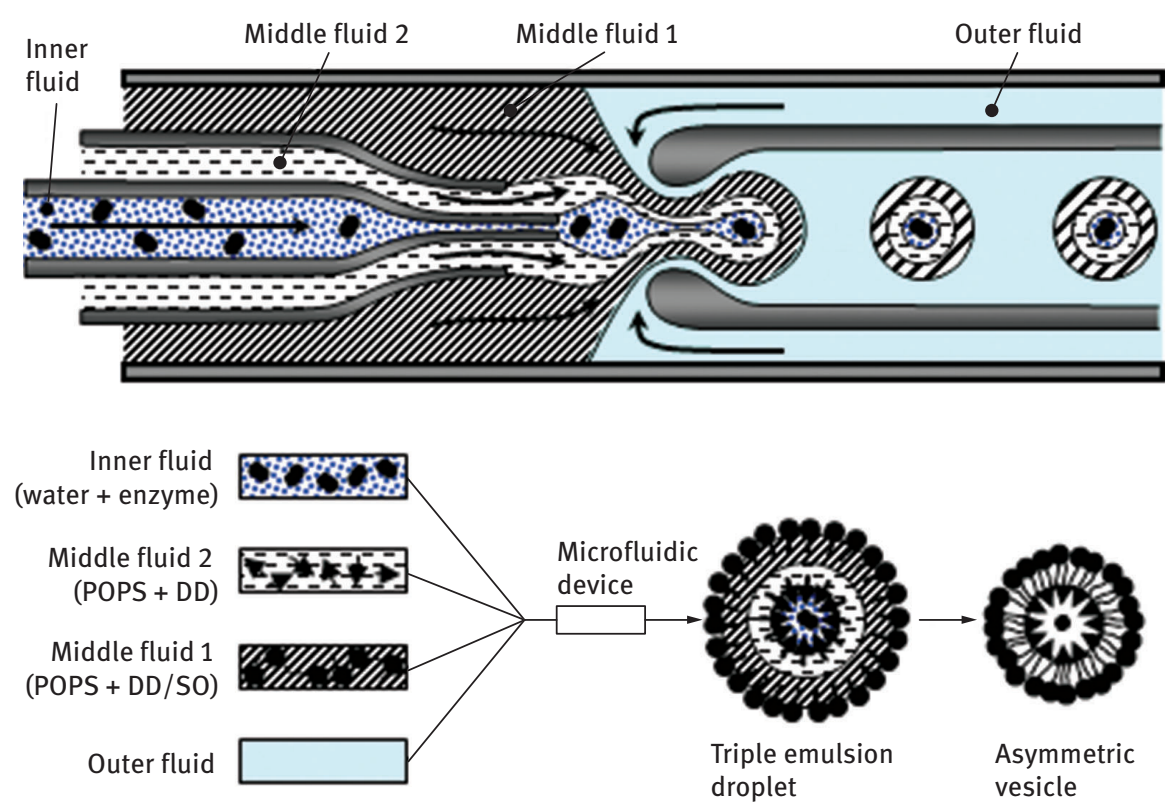

Fig. 2.14: Generation of enzyme-loaded asymmetric vesicles in a flow focusing microfluidic device (FFMD).

A microfluidic device depicted in Fig. 2.15 has been used to generate core/shell W/O/W emulsions with a diblock copolymer dissolved in the middle hydrophobic fluid [4]. The inner fluid is a buffer solution containing enzyme, and the outer phase is a mixture of $80 \%$ (v/v) glycerol in distilled water (Fig. 2.16). Glycerol was added to the outer fluid to increase its viscosity, which improves the efficiency of the flow focusing. The middle phase is a volatile organic solvent; the evaporation of the organic solvent causes the amphiphilic block copolymer poly(normal-butyl acrylate)-poly(acrylic acid) (PBAPAA) to self-assemble into layers on the concentric interfaces of the double emulsion droplets, forming an enzyme-loaded polymerosome. The PBA is the hydrophobic block in the copolymer molecule, whereas the PAA is the hydrophilic block. It is critical that the dissolved macromolecules are mostly unimers as opposed to larger aggregates because such aggregates do not efficiently stabilize the inner droplets against coalescence with the outer phase. Using this microfluidic approach, it was also feasible to prepare multicompartment polymersomes consisting of many internal compartments starting from $\mathrm{W} / \mathrm{O} / \mathrm{W}$ emulsions consisting of several inner drops [4]. 


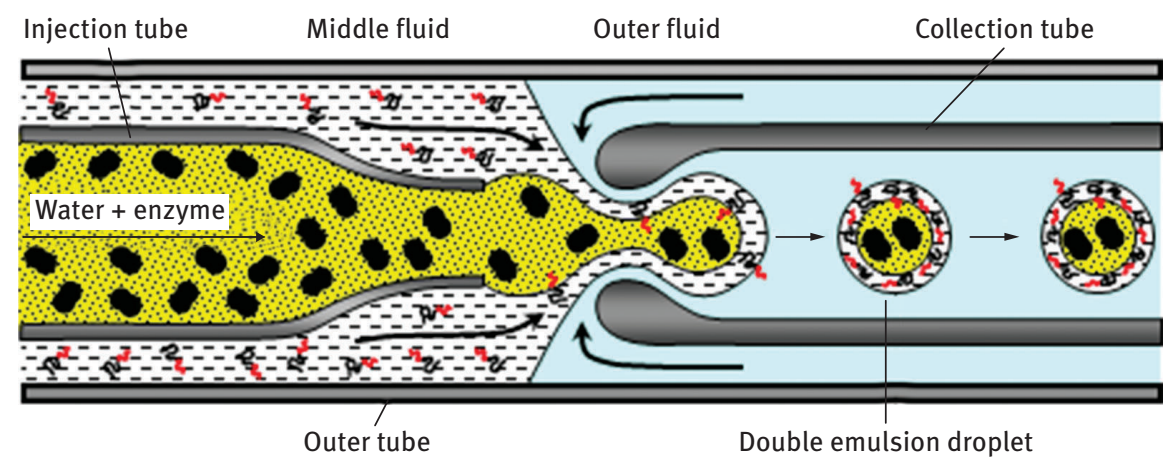

Fig. 2.15: Fabrication of enzyme-loaded polymerosomes in a FFMD.

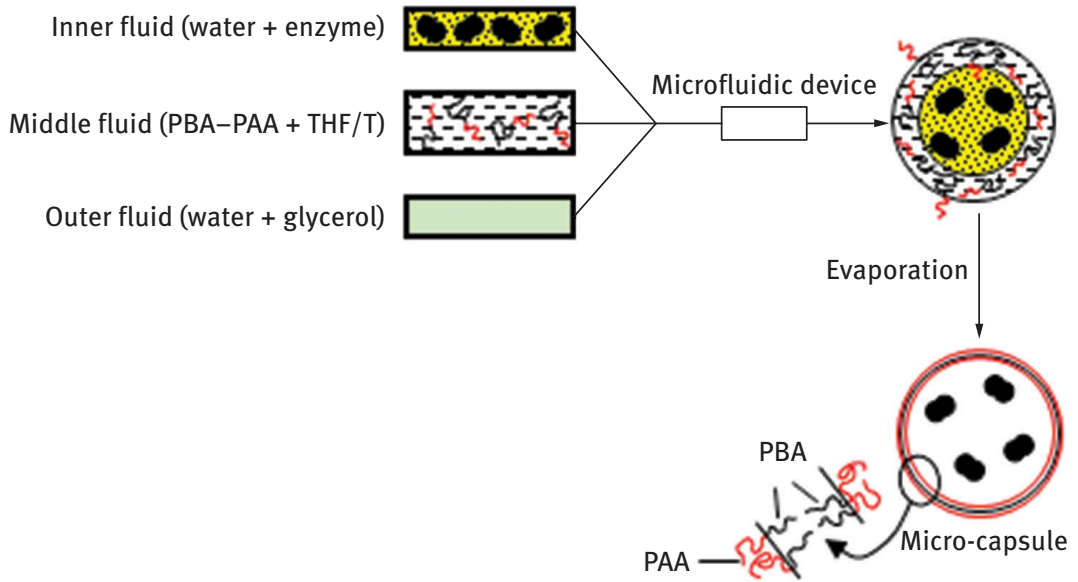

Fig. 2.16: Production steps in the fabrication of enzyme-loaded polymerosomes.

\subsubsection{Microgels}

Hydrogels are cross-linked hydrophilic polymer networks that can absorb and hold a large amount of water due to their hydrophilic nature [101]. They can be prepared starting from monomers, prepolymers or existing hydrophilic polymers. A threedimensional gel network can be formed by chemical (covalent) crosslinking using crosslinkers such as glytaraldehyde and EDGA or by physical gelation, which can involve a coil-to-helix transition (agarose and gelatine gels), hydrogen bonding, stereocomplexation, hydrophobic interactions and charge interactions (calcium alginate and chitosan-TPP gels). Microgels are hydrogel microspheres that can easily be fabricated by charge interactions (ionotropic gelation). The main strategies for fabrication of microgels by ionotropic gelation are emulsification/internal gelation and 
atomization (or nozzle extrusion)/external gelation. In the internal gelation method, emulsified droplets contain a gel-forming polymer (e.g. sodium alginate), enzyme and a crosslinking agent in its inactive form (e.g. $\mathrm{CaCO}_{3}$ ) whereas the organic continuous phase contains a species (e.g. $\mathrm{H}^{+}$) that diffuses into the droplets and triggers the dissociation of the crosslinking agent. For a sodium alginate $/ \mathrm{CaCO}_{3} / \mathrm{H}^{+}$system:

$$
\mathrm{CaCO}_{3}+2 \mathrm{H}^{+} \longrightarrow \mathrm{Ca}^{2+}+\mathrm{H}_{2} \mathrm{O}+\mathrm{CO}_{2} \uparrow
$$

The released $\mathrm{Ca}^{2+}$ ions bind to the guluronic residues of sodium alginate, crosslinking the polymer and causing the gelation of the enzyme-loaded droplets [102]. This process is reversible and the resultant beads are soluble in an aqueous solution containing monovalent ions due to exchange of $\mathrm{Ca}^{2+}$ ions with non cross-linkable monovalent ions. Irreversible gelation can be achieved using alginate with phenol moieties in the side chains (Alg-Ph), which can be synthesized through the conjugation reaction of alginate and tyramin. Alg-Ph can be subjected to irreversible crosslinking via oxidative $\mathrm{C}-\mathrm{C}$ and $\mathrm{C}-\mathrm{O}$ coupling of phenol moieties in the presence of hydrogen peroxide and peroxidase. Sakai et al. [103] fabricated cell-loaded Alg-Ph microgels using a co-flow microfluidic device. The disperse phase was Alg-Ph solution containing cells and horseradish peroxidase (HRP); the continuous phase was hydrogen peroxide dissolved in liquid paraffin. Hydrogen peroxide can penetrate into alginate droplets causing HPR-catalyzed crosslinking of alginate. Enzymatic crosslinking of Alg-Ph is a suitable technique for screening for Glucose oxidase [104].

\subsubsection{Segregation by membranes}

In this method, enzymes are localized between hollow fiber membranes, either freely suspended or entrapped within a gel. If they are freely suspended, the enzyme suspension can be placed outside the fibers (within the shell) or in the fiber lumens. Zhang et al. [89] immobilized carbonic anhydrase in PAA-AAm/HT nanocomposite hydrogel filled between hollow fibers. The reactor was designed for selective separation of low concentration $\mathrm{CO}_{2}$ from gas streams. Zhang et al. [105] confined glucosidase between two sheets of flat ultrafiltration membranes to convert maltose to isomaltooligosaccharides.

\subsubsection{Covalent binding}

The most frequently used enzyme insolubilization technique is the formation of covalent bonds between the enzyme and the membrane matrix. The binding reaction must be performed under conditions that do not cause a loss of enzymatic activity, and the active site of the enzyme must be unaffected by the reagents used. The functional groups of proteins suitable for covalent binding under mild conditions include: (i) the 
alpha amino groups of the chain and the epsilon amino groups of lysine and arginine; (ii) the alpha carboxyl group of the chain end and the beta and gamma carboxyl groups of aspartic and glutamic acids; (iii) the phenol ring of tyrosine; (iv) the thiol group of cysteine; (v) the hydroxyl groups of serine and threonine; (vi) the imidazile group of histidine; and (vii) the indole group of tryptophan. A small number of reactions have been designed to couple with functional groups on the protein other than the amino and phenolic residues. Aminoethyl cellulose has been coupled to the carboxylic acid residues of enzymic protein in the presence of carbodiimide, and thiol residues of a protein have been oxidatively coupled to the thiol groups of a cross-linked copolymer of acrylamide and $\mathrm{N}$-acryloyl-cystein. It is possible in some cases to increase the number of reactive residues of an enzyme in order to increase the yield of insolubilized enzyme and to provide alternative reaction sites to those essential for enzymic activity. As with cross-linking, covalent bonding should provide stable, insolubilized enzyme derivatives that do not leach enzyme into the surrounding solution. The wide variety of binding reactions and membranes with functional groups capable of covalent coupling, or being activated to give such groups, makes this a generally applicable method of immobilization, even if very little is known about the protein structure or active site of the enzyme to be coupled.

Fig. 2.17 illustrates modification steps used for covalent immobilization of the enzyme pig liver esterase on the nylon (polyamide) membrane: (a) Epoxy terminal group. The membrane is modified by recirculation of a $1 \mathrm{M}$ solution of 1,4-butanediol diglycidyl ether in borate buffer at $\mathrm{pH} 9$; (b) Imidazol terminal group. $0.4 \mathrm{M}$ solution of carbonyl diimidazole (CDI) is re-circulated through the module for $30 \mathrm{~min}$. After washing with acetonitrile and water, a $1 \mathrm{M}$ solution of 1,6-hexanediamine in a borate buffer at $\mathrm{pH} 8.5$ is re-circulated through the module for $24 \mathrm{~h}$. The CDI reaction step is then repeated; (c) Amino terminal group. The procedure is the same as the one to obtain the imidazol terminal group, without the final CDI reaction step; (d) Carboxylic acid terminal group. A solution of glutaraldehyde and $0.1 \mathrm{M}$ cyanoborohydride in borate buffer at $\mathrm{pH} 9.4$ is recirculated through the module for $4 \mathrm{~h}$. After washing with fresh buffer, a $0.4 \mathrm{M}$ solution of aminocaproic acid and $0.1 \mathrm{M}$ cyanoborohydride in borate buffer is re-circulated overnight [12].

Belleville et al. [106] and Lozano et al. [107, 108] have developed the enzyme immobillization technique based on covalent binding of enzymes on polymer-coated porous ceramic membranes. The method involves three main steps illustrated in Fig. 2.18. First, the inner surface of zirconia/ $\alpha$-alumina membrane tube is coated with an ultra-thin gel layer obtained during cross-flow filtration of an inert protein solution such as gelatin [109]. The dynamic protein layer is then activated with a cross-linking agent (glutaraldhehyde) and finally, the activated layer is brought into contact with the enzyme solution in order to covalently bind the enzyme. Using this procedure, the enzyme $\alpha$-chymotrypsin has been immobilized onto a gelatin-zirconia or gelatin- $\alpha$-alumina dynamic membrane and used for the organic-phase synthesis of the analgesic dipeptide, kyotorphin, from N-benzoyl-L-tyrosine ethyl ester and 


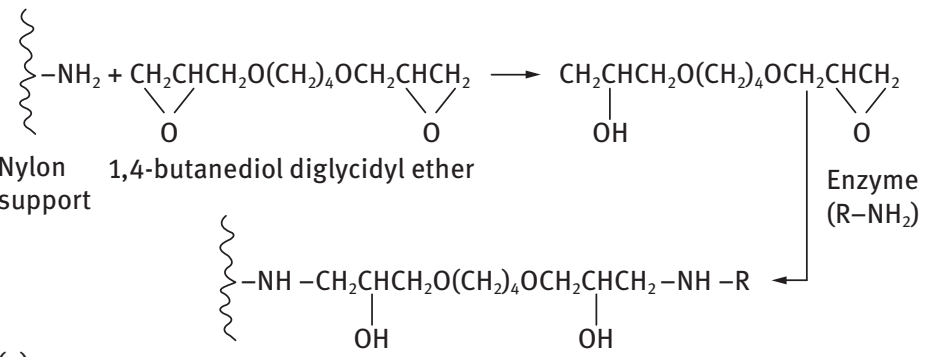

(a)

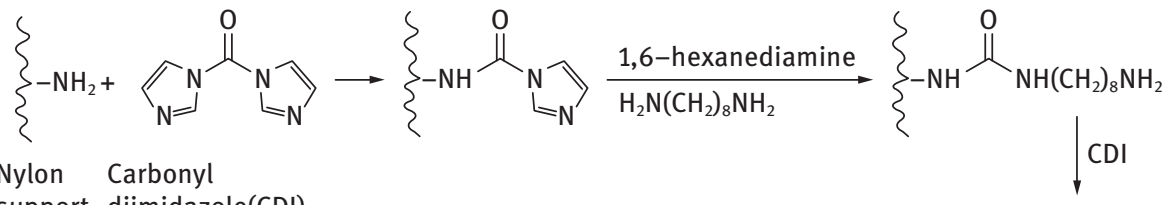
support diimidazole(CDI)

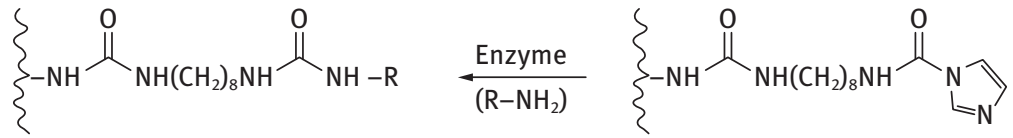

(b)

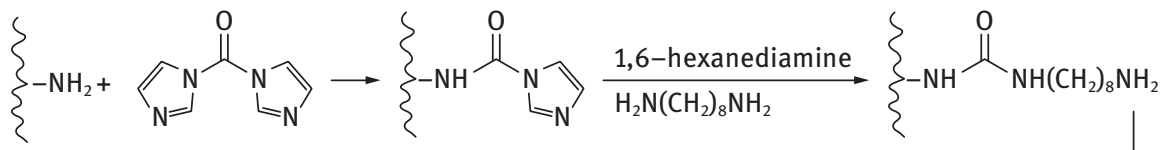

Nylon Carbonyl

support diimidazole(CDI)

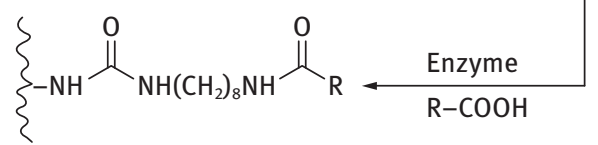

(c)

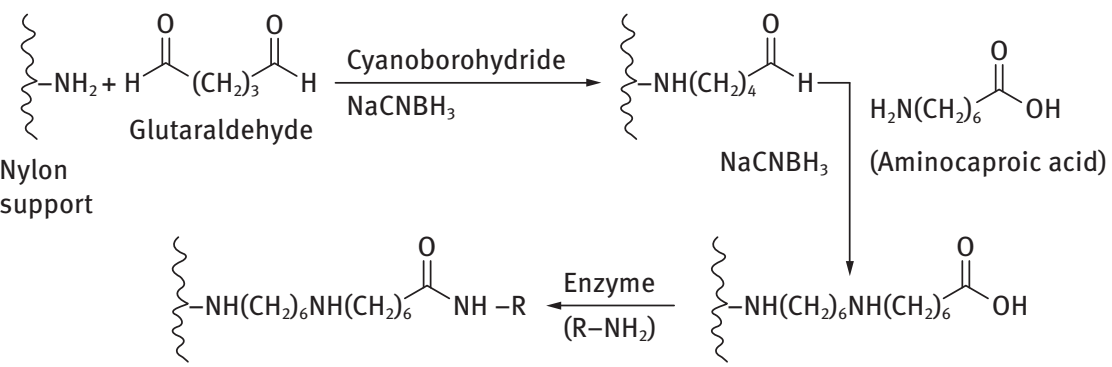

(d)

Fig. 2.17: Modification steps used for covalent immobilization of the enzyme pig liver esterase on nylon membrane: (a) epoxy terminal group; (b) imidazol terminal group; (c) amino terminal group; (d) carboxylic acid terminal group [12]. 

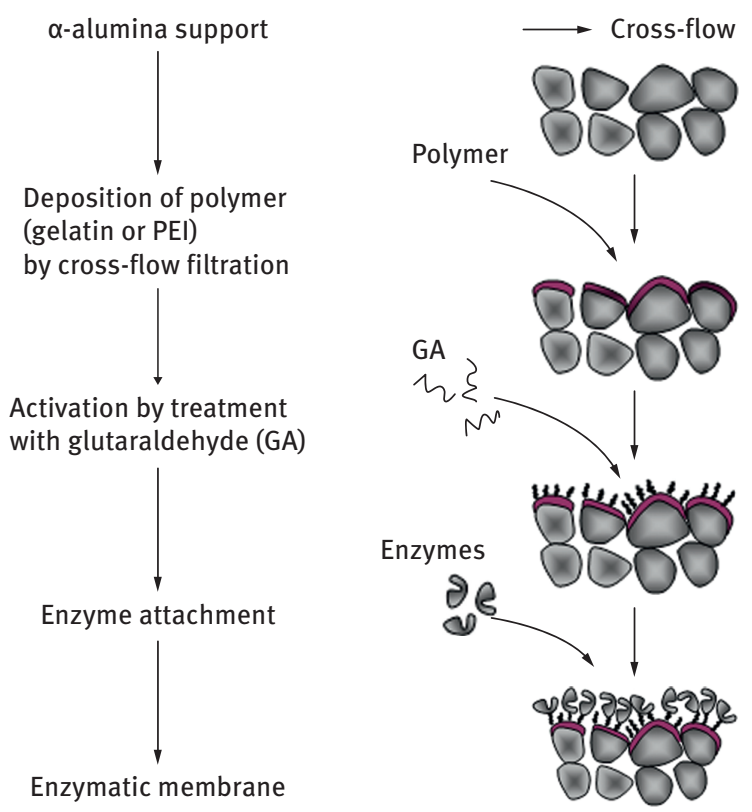

Fig. 2.18: Procedure for preparing catalytic membrane by the covalent attachment of the enzyme onto $\alpha$-alumina support coated by hydrophilic polymers [110].

L-argininamide [107]. The hydrophilic nature of the gelatin coating layer provided good protection of the enzyme structure against deactivation by a direct contact with the organic solvent.

The method for preparing enzyme ceramic membrane has been improved by using polyethyleneimine (PEI) as a coating agent with the higher content of free primary amino groups, which allowed an increase in the number of potential covalent links for the enzyme attachment. The best results were obtained with a $50 \%$ mixture of gelatin and PEI [110]. The application of this procedure to prepare immobilized Candida antarctica lipase B for the synthesis of butyl butyrate from vinyl butyrate and 1-butanol and butyl laurate from butyl acetate and lauric acid in supercritical carbon dioxide ( $\left.\mathrm{SC} \mathrm{CO}_{2}\right)$ and different organic solvents (acetonitrile, acetone and hexane) has been demonstrated by Lozano et al. [108, 111], Gumi et al. [112] and Mori et al. [113].

Contrary to the applications where $\mathrm{SC} \mathrm{CO}_{2}$ acts as a solvent, Pomier et al. [114, 115] have developed another process in which $\mathrm{SC} \mathrm{CO}_{2}$ was mixed together with a highly viscous oil to obtain a heterogeneous mixture of reduced viscosity. The mixture was then brought into contact with the enzymatic membrane to conduct esterification reactions on oil. The main advantage is to avoid the use of high temperatures and the addition of organic solvents. This process has been tested through the lipase-catalyzed interesterification reaction of castor oil triglycerides (TG) with methyl oleate:

$$
\text { Castor oil TG + methyloleate methyl ricinoleate }+\mathrm{TG}
$$




\subsection{Laminated (multilayer) enzyme membrane reactors}

\subsubsection{Concept}

Matson and Quinn [116, 117] have developed a laminated (multi-sandwiched) membrane reactor that enables a catalytic reaction with simultaneous product separation and recovery. Fig. 2.19 shows a cross section of one such two-layer composite membrane capable of product separation and enrichment. It consists of permselective and catalytic membrane layers contacted on one side with a feed mixture of reactant (R) and inert material (I); the other membrane surface contacts a sweep stream (S), the purpose of which is to carry the product (P) out of the reactor. The permselective film permits reactant to diffuse into the catalytic membrane layer, but it is impermeable to at least one reaction product (e.g. product P in Fig. 2.19 (a) and (b)) preventing its backdiffusion into the feed stream.

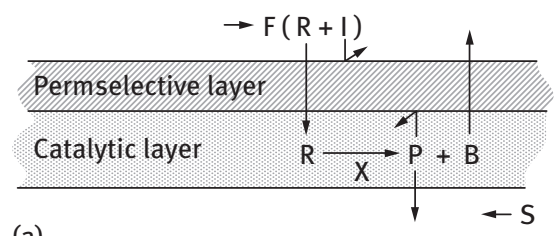

(a)

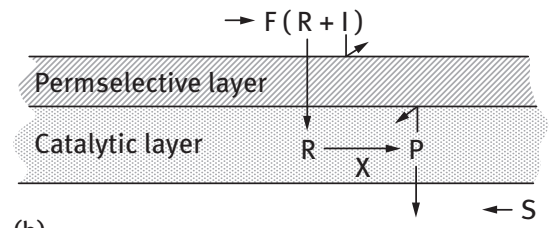

(b)
Fig. 2.19: Schematic view of the two-layer composite membrane showing the diffusion and interaction of materials during a single stage catalytic reaction. Reaction scheme (a): $R \longrightarrow P+B$; Reaction scheme (b): $\mathrm{R} \longrightarrow \mathrm{P}$.

For carrying out a multiple catalytic reaction, the three-layer composite membrane shown in Fig. 2.20 should be used, with its catalytic membrane layer being sandwiched between the two permselective layers. The catalytic membrane contains two different catalysts ( $\mathrm{X}$ and $\mathrm{Y}$ ). The permselective membrane layer 1 should be substantially impermeable at least to the intermediate precursor (A) of the desired end product (P) and preferably to the inert component, so as to substantially maintain the inert component on the feed stream side of the membrane. Likewise, when one or more undesired reaction byproducts are formed in the reaction, the permselective membrane layer 1 should be preferably permeable to such byproducts, so as to ensure their substantial diffusion into the feed stream and thus separation from the desired end product. In practice, the permselective membrane layers are immobilized liquid membranes (ILMs), ion exchange membranes (IEMs), and facilitated transport membranes. Particularly suitable membranes for this purpose are immobilized liquid 
membranes consisting of a water-immiscible solvent for the particular reactant being employed, held by capillarity in a microporous hydrophobic support membrane. ILM's and IEM's are particularly suitable for reactions which form charged products from electrically neutral reactants; the difference in solubilities of electrolytes and non-electrolytes in organic solvents can be exploited to form ILM's of high selectivity, and Donnan exclusion of an electrolyte from an IEM is a second basis for selectivity. In addition, a chemical reaction can introduce or remove functional groups, with the result that a highly selective facilitated or coupled transport system may be available either for the reactant or product.

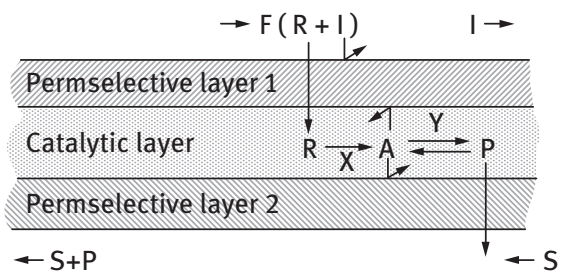

Fig. 2.20: Schematic view of the three-layer composite membrane during a two stage catalytic conversion reaction catalyzed by $X$ and $Y$ catalysts.

Another feature of this membrane reactor is its ability to enrich the product, i.e. to deliver product at a concentration higher than that of the reactant in the feed stream. If the permselective film is essentially impermeable to the product, the concentration of this component in the exiting product stream will be inversely proportional to the product stream flow rate. Hence, high degrees of product enrichment can be realized by operating the reactor at high feed-to-product stream flow rate ratios. Typically, the feed stream flow rate will be adjusted to achieve the desired conversion; the product stream flow rate then controls the degree of product enrichment [1]. The high feed-toproduct stream flow rate ratios automatically ensure high fractional recoveries of inert in the exiting feed stream. Even in the limiting case where the membrane is infinitely permeable to the inert (so that the concentrations of inert on both sides of the membrane are the same), the molar ratio of inert recovered in the exiting feed stream to that carried away with the sweep fluid is approximately equal to the flow rate ratio.

Neither product separation nor enrichment can be accomplished simultaneously with chemical conversion in conventional reactors employing catalyst particles, because all components exit the reactor via a common stream, and product enrichment is prohibited by the material balance. On the other hand, the laminated membrane reactor is an integrated multifunctional device capable of performing these three operations of catalysis, separation and concentration simultaneously rather than separately in three different pieces of equipment, as shown in Fig. 2.21. 


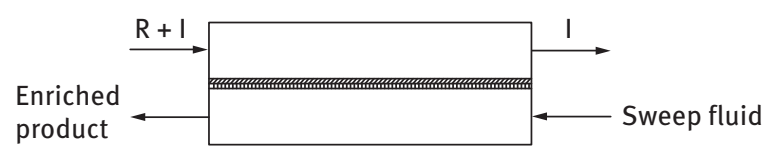

(a) Membrane reactor

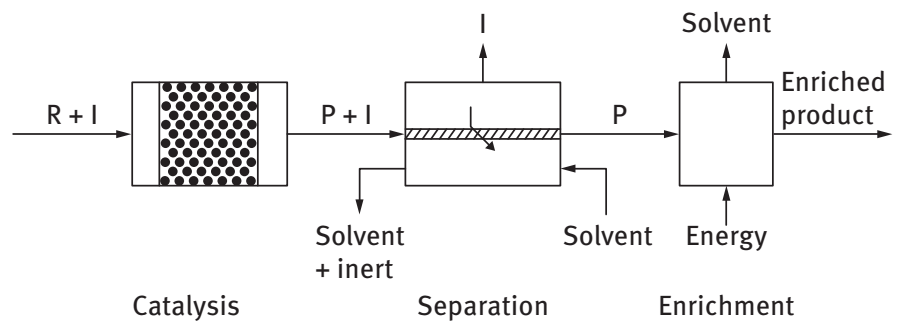

(b) Conventional reactor

Fig. 2.21: Comparison of (a) laminated membrane reactor, in which catalysis, separation and enrichment are integrated within a single device, and (b) conventional process, in which catalytic reaction, product separation and product recovery are accomplished in three separate devices $(R=$ reactant, $\mathrm{I}=$ inert, $\mathrm{P}=$ product).

\subsubsection{Application}

The ability of $\alpha$-chymotrypsin to hydrolyse ester derivates of the aromatic L-amino acids and other related compounds while leaving the D-enantiomers unconverted forms the basis for the preparative resolution of these compounds. Enzymatic resolution based on the esterase function of chymotrypsin has been demonstrated for tyrosine [118], phenylalanine [119], tryptophan [120], aspartame [121], dopa [122], and many other related compounds [123]. One example of substrate capable of being resolved by $\alpha$-chymotrypsin is $\mathrm{N}$-acetyl tyrosine ethyl ester (ATEE):

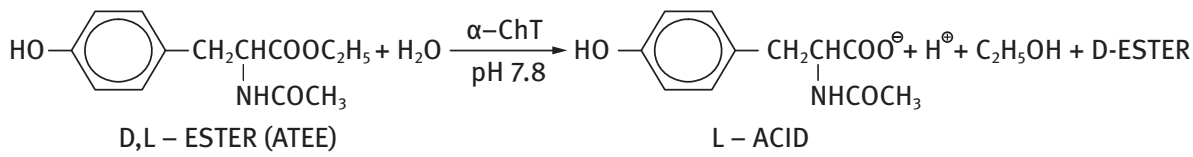

The application of a laminated membrane reactor to the optical resolution of amino acid ester derivates is illustrated in Fig. 2.22 [117]. The reactor consists of a two-layer sandwich of a chymotripsin enzyme membrane in intimate contact with an immobilized liquid membrane (ILM). The enzyme membrane consists of chymotrypsin covalently bound to MF mixed cellulose ester membrane. ILM should be permeable to electrically neutral species such as esters, but impermeable to charged species such as the dissociated L-acid. The ILM used by Matson and Quinn [117] consisted of a microporous, hydrophobic polytetrafluoroethylene (PTFE) support membrane impregnated with decanol that was trapped within the pores by capillary action. Such a membrane combines the desirable permeation properties of the liquid phase (e.g. high ester sol- 


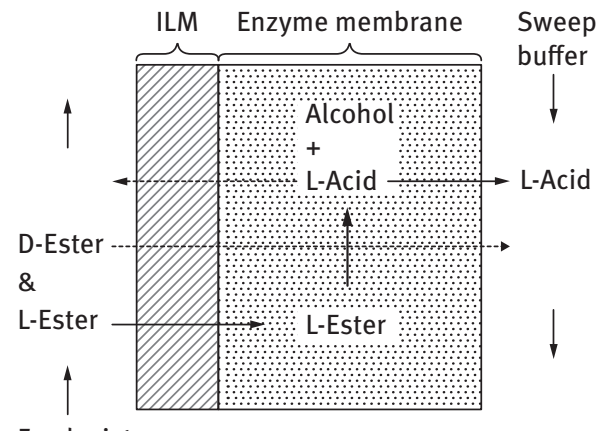

Feed mixture

(a)

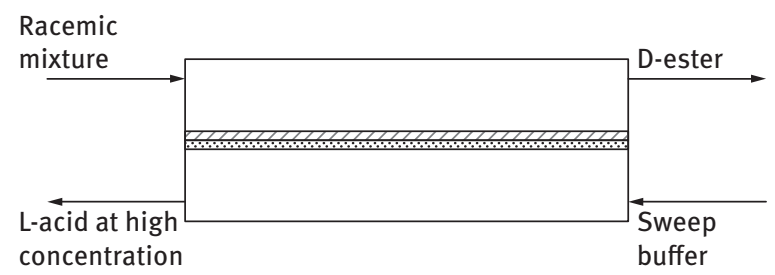

(b)

Fig. 2.22: Application of laminated enzyme membrane reactor to the resolution of amino acids:

(a) membrane function and (b) reaction operation [117]. The solid arrow lines represent the preferential flux directions.

ubility and diffusivity) with the mechanical properties and geometry of the porous solid support. Both esters dissolve easily into the ILM film and diffuse to the enzyme membrane where only L-ester is converted to its acid form, L-acid. Since the L-acid is charged at the $\mathrm{pH}$ at which the enzyme operates, it cannot dissolve into the ILM and diffuse back into the feed stream but is forced to migrate into the sweep buffer. By operating the reactor at high feed-to-product flow rate ratios, most of the inert D-ester will be recovered in the exiting feed stream and the L-acid will be removed at a higher concentration than that of the L-ester in the racemic feed mixture. In fact, optical resolution occurs when the reactor of Fig. 2.22 is operated to give high L-ester conversion (i.e. at a large dimensionless space time $\Phi$ ) and high L-acid enrichment (i.e. at a large flow rate ratio $\phi$ ). The former condition results in an exiting feed stream that contains primarily D-ester that has been stripped of most of the L-ester, whereas the latter condition ensures a high ratio of L- to D-acid in the product stream.

The laminated membrane reactor was tested for separation of optical isomers from a racemic feed mixture composed of $2 \mathrm{mM}$ D,L-ATEE in $0.10 \mathrm{M}$ phosphate buffer at pH 7.8 [117]. The separation results summarized in Fig. 2.23 (a) demonstrate the ability of the multilayer membrane reactor to accomplish optical resolution at high efficiency. Still higher feed and product stream optical purities can be attained by increasing the 
membrane reactor space time $\Phi$ and the flow rate ratio $\theta\left(V_{F} / V_{P}\right)$, respectively. The dimensionless membrane reactor space time $\Phi$ is given by $P A / V_{F}$, where $A$ is the membrane area, $V_{F}$ is the feed stream flow rate and $P$ is the ILM permeability to the reactant (L-ester): $P=K D \varepsilon /(\delta \tau)$, where $K$ is the dimensionless distribution coefficient of the reactant between decanol and the feed stream, $D$ is the diffusivity of the reactant in decanol and $\varepsilon, \delta$, and $\tau$ are the porosity, thickness and tortuosity of the support membrane, respectively. The degree of enantiomeric purity of product streams was estimated by their enantiomeric excess: $e e=\left(X_{D}-X_{L}\right) /\left(X_{D}+X_{L}\right)=2 X_{D}-1$, where $X_{D}$ and $X_{L}$ are the mole fraction of $\mathrm{D}$ - and L-isomer in the exit stream, respectively. At the operating conditions shown in Fig. 2.23 (a), both product streams contain one of the two enantiomers at optical purities of $86 \%$, whereas the optical purity of the racemic feed mixture was $0 \%$.

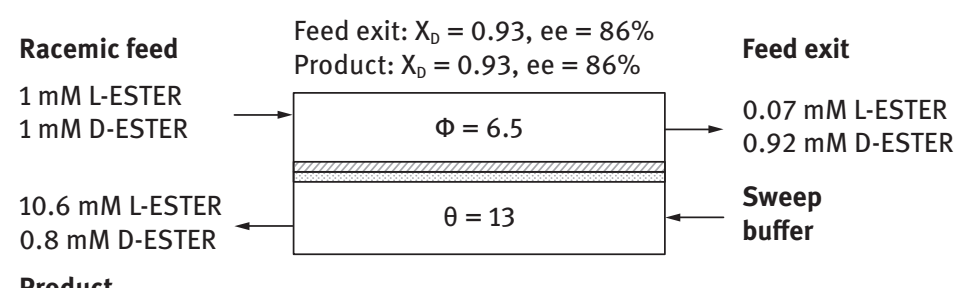

Product

(a)

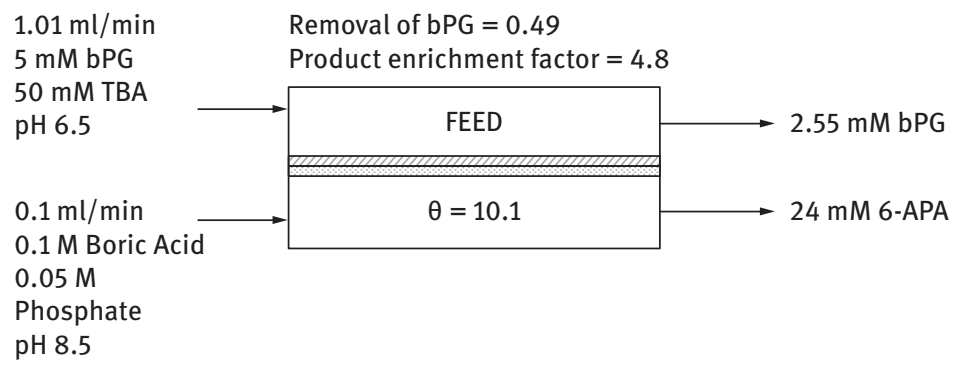

(b)

Fig. 2.23: Typical performance of laminated enzyme membrane reactor in: (a) amino acid resolution [117]; and (b) enzymatic deacetylation of benzyl penicillin [124].

The laminated membrane reactor was also used to convert benzylpenicillin (bPG) to 6-aminopenicillanic acid (6-APA) and phenylacetic acid (PhAA) by penicillin acylase (PA) [124]:

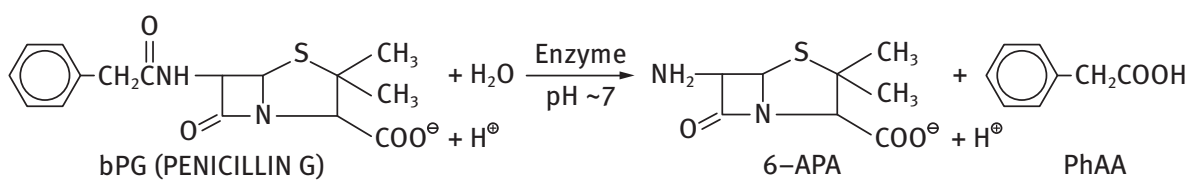


The transport of negatively charged bPG (at neutral $\mathrm{pH}$ ) through an apolar ILM, (consisting of a porous Teflon membrane impregnated by decanol) was promoted by the formation of a neutral complex between the bPG anion and tetrabutylammonium cation present in the feed stream [125]. This coupling significantly increased the distribution of bPG into the apolar membrane. The product 6-APA could not dissolve to any great extent in the ILM due to a higher $\mathrm{pH}$ in the product stream and was collected in the sweep buffer at high concentrations (Fig. 2.23 (b)).

Laminated enzyme membrane reactor technology suffers from two limitations: it is relatively complicated and does not utilize convective transport which is faster than molecular diffusion [126]. To extend and simplify this concept, Matson [97] has developed multiphase membrane reactors in which a single enzyme membrane is positioned between aqueous and organic flow streams. This approach is discussed in the following section.

\subsection{Biphasic (multiphase) membrane bioreactors}

\subsubsection{Concept}

Instead of trapping the organic phase in one membrane (ILM) and using a bilayer membrane sandwich to separate two aqueous solutions, in biphasic (multiphase) membrane reactors a single hydrophilic, enzyme-activated porous membrane is used to separate immiscible aqueous and organic streams [97, 127, 128]. By virtue of the hydrophilicity of the membrane and the slight organic-to-aqueous-phase pressure difference imposed across the membrane, the aqueous/organic interface is fixed at that side of the membrane that is in contact with the organic stream. A poorly watersoluble reactant $(\mathrm{R})$ partitions into the membrane and is enzymatically converted to water-soluble product $(\mathrm{P})$, which subsequently diffuses out into the aqueous stream (Fig. 2.24). The enzyme-activated membrane serves as a high-surface-area organic/ aqueous phase contactor, as an organic/aqueous phase separator, and as an interfacial biocatalyst. By placing hydrophilic hollow fiber membranes at the interface between the two immiscible phases (Fig. 2.25(a)), it is possible to provide a large organic/aqueous contact area without the necessity of dispersing one immiscible phase within the other, as in conventional emulsion-based multiphase systems. By controlling flow rate ratios of the aqueous and organic streams, it is possible to obtain a product at a concentration higher than the concentration of its organic-phase precursor in the feed stream, like in previously discussed laminated membrane reactors.

Conventionally, enzyme-catalyzed conversions of sparingly water-soluble substrates are conducted in a two-phase system in which free enzyme is dissolved in a continuous, aqueous phase and substrate (and often products) are present in a separate, immiscible organic phase dispersed within the aqueous phase [129]. A novel approach in emulsion membrane reactor systems is the dispersion of the organic 


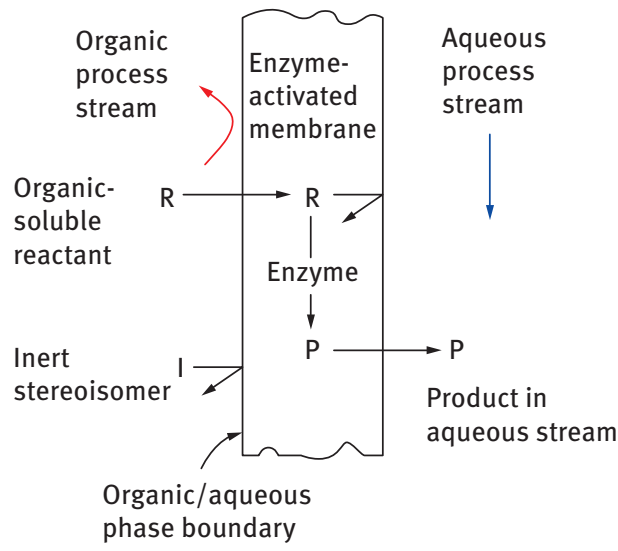

Fig. 2.24: Schematic, cross-sectional view of the enzyme-activated membrane in a multiphase membrane reactor process [134].

phase within the aqueous phase using membrane emulsification [130, 131]. Alternatively, the aqueous phase may be dispersed within a continuous organic phase forming a water-in-oil emulsion (W/O). Another approach to the use of enzymes in conjunction with water-insoluble substrates involves conducting the reaction in substantially water-free organic reaction media [132] or in the presence of reversed micelles containing entrapped enzymes [133]. While some limited success has been achieved with these approaches, they are not very general. In particular, many enzymes are altogether inactive in neat or water-saturated organic solvents, and those that do retain some activity often exhibit altered selectivity or reduced stability.

If it is desirable to immobilize the enzyme on a high-surface-area support in order to facilitate its recovery and reuse, a triphasic reaction scheme may be employed (Fig. 2.25(b)). In three-phase systems, the water-insoluble substrate is supplied in an organic phase (with or without added organic solvent), with the organic phase being dispersed in a continuous aqueous phase. The enzyme is then immobilized within a third, solid phase (porous particles), and the three phases are contacted in a stirred vessel or packed bed. Excessive aqueous phase mass transfer resistances and phase separation and product recovery problems characterize this approach. Using hollow fiber membranes to separate the aqueous and organic streams, the substrate is brought close to the catalyst reducing diffusion limitations.

Enzymes are usually entrapped within a spongy fiber wall, as illustrated in Fig. 2.26. The interior or luminal fiber surface consists of an enzyme-retentive skin with a nominal molecular-weight cut-off of typically about $30 \mathrm{kDa}$, while the exterior fiber surface is open and readily penetrated by enzymes [91]. This asymmetric structure immobilizes the enzyme by localizing it between two barriers: (i) the enzymeimpermeable interior skin; and (ii) the aqueous/organic interface maintained at the exterior surface of the hollow fiber. The size of the enzyme prevents it from diffusing across the skin, while the low organic-phase solubility of the enzyme prevents it from being carried away by the organic stream. Enzymes are loaded into the porous fiber 

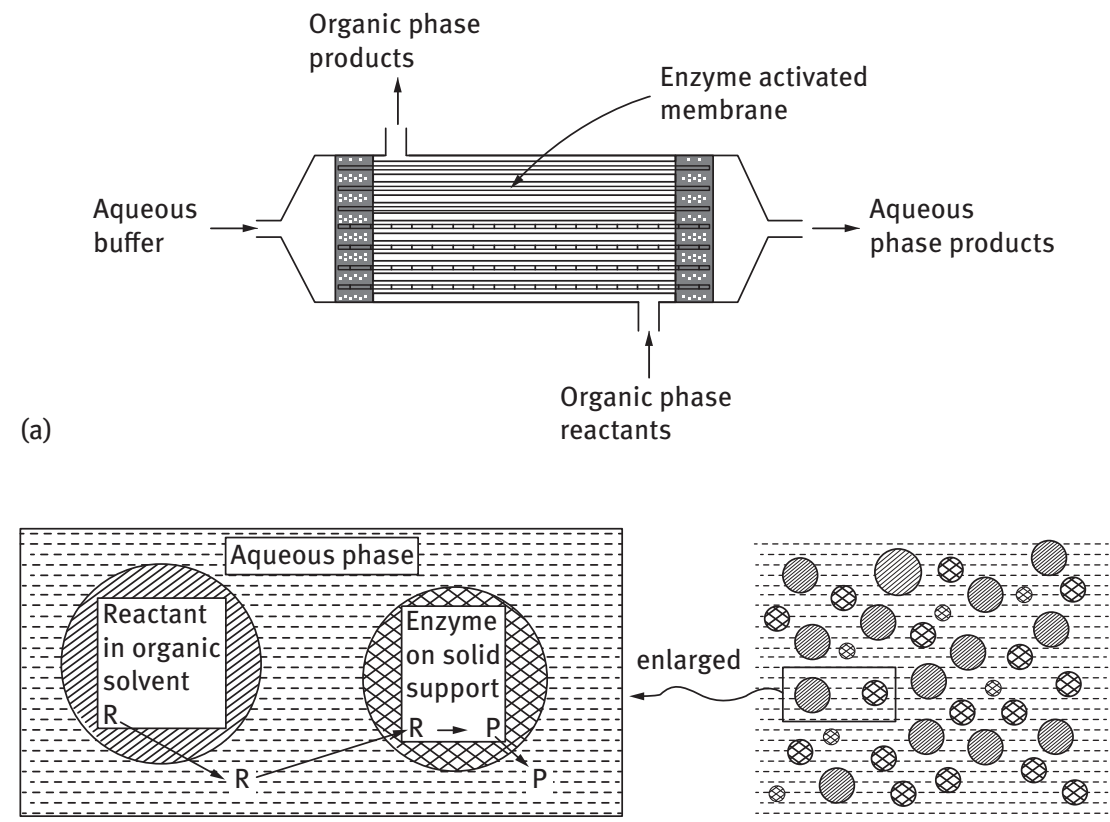

(b)

Fig. 2.25: Comparison of multiphase immobilised enzyme reactors: (a) hollow-fiber dispersion-free membrane reactor; (b) conventional dispersion-based reactor [91].

walls by ultrafiltering aqueous enzyme solution in the shell-to-lumen direction for several hours; the UF skin at the luminal surface of the fiber retains the enzyme within the interior. Once the enzyme is in place, the external aqueous phase is replaced by the organic phase feed stream. The degraded enzyme can easily be replaced by reversing the pressure differential, backflushing, and then reloading. Alternative approaches rely on the formation of dynamic enzyme-gel-polarized membranes atop the surface of ultrafiltration membranes [134] or the covalent attachment [12].

\subsubsection{Application}

Multiphase membrane reactors are appropriate for enzymatic conversions that involve sparingly water-soluble substrate or product. An example is the separation of racemic mixtures on the preparative scale, where the reactants are often sparingly soluble in aqueous solution. Since enzymes generally operate in aqueous solutions and not organic solvents, it has proven difficult to facilitate the enzymecatalyzed bioconversion and subsequent separation of poorly water-soluble optical isomers. Multiphase (biphasic) membrane reactors offer many advantages in managing these sorts of reactions $[127,128,134]$. Typically, the membrane immobilized 


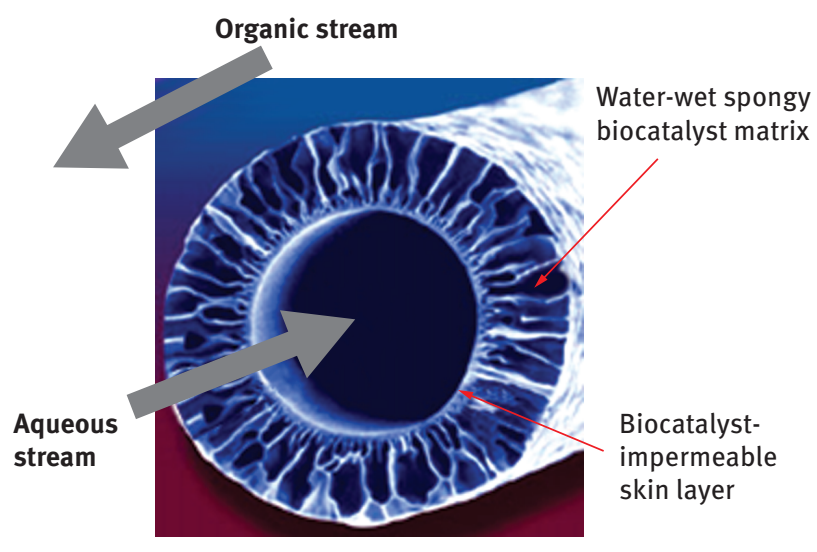

Fig. 2.26: Reversible enzyme containment in multiphase enzyme hollow-fiber membrane reactor.

enzyme preferentially converts one reactive stereoisomer in a racemic ( $\mathrm{R}$ and $\mathrm{S}$ ) feed mixture of water-insoluble feed isomers to a water-soluble product isomer of altered chemical composition. Enzymes that are particularly useful for this conversion are hydrolytic enzymes such as lipases, carboxyl esterases and amidases. The watersoluble product isomer exits the reactor via the aqueous stream, while the unreactive water-insoluble reactant isomer ( $\mathrm{S}$ or $\mathrm{R}$ ) in the racemic feed leaves the reactor via the organic stream. The overall result is that these two species with different stereoconfigurations will be partially isolated from one another. The example of this method is the lipase-catalyzed optical resolution of racemic feed mixtures of esters such as methyl ester of 4-methoxy-3-phenylglycidic acid (MMPG), a chiral intermediate used in the production of diltiazem [91, 135], naproxen methyl ester [136, 137], cyanomethyl[2-(4-isobutylphenyl)propionate] [138], 2-hydroxy octanoic acid methyl and butyl ester [16], 1-phenylethyl acetate and 1-phenyl-1-propyl acetate [90, 139], 2-ethoxyethyl-ibuprofen ester [96], and glycidyl butyrate [139]. In this case, a racemic mixture of esters dissolved in an organic solvent is stereospecifically hydrolyzed by the enzyme, and the optically enriched organic acid (and water-soluble alcohol co-product) thereby produced are removed by an aqueous stream, as shown in Fig. 2.27.

The net result is that a mixture of $\mathrm{R}$ and $\mathrm{S}$ optical isomers is separated into two streams; the organic-phase stream contains the unconverted lipophilic isomer present in the original feed stream, while the aqueous stream contains the water-soluble enzymatic reaction product possessing the opposite stereochemical configuration. Overall yields of the desired enantiomer may be further enhanced by racemization of the material in one of the exiting streams, followed by its recycle to the inlet of the resolution process as shown in Fig. 2.28. 


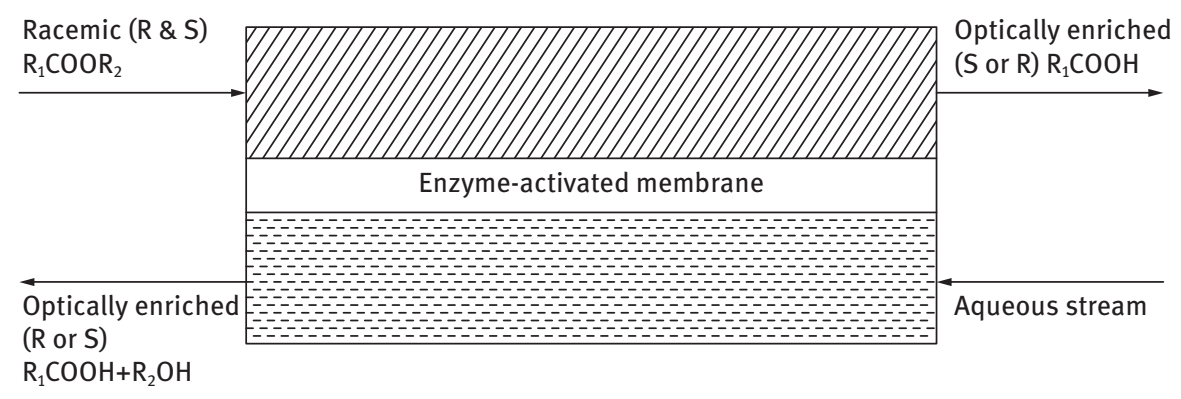

Fig. 2.27: Schematic representation of a method for the resolution of a racemic mixture of organicsoluble esters (chiral center on acid moiety).

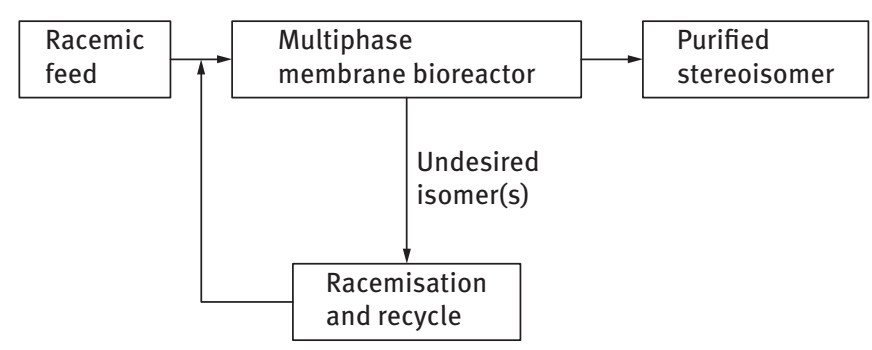

Fig. 2.28: Example of an integrated resolution/racemisation/recycle process for the production of a singly optically purified product, in which the undesired isomers are racemised and recycled internal to the process with the net result that only material of the desired stereochemical configuration is produced [134].

In the same way, the multiphase enzyme membrane reactor process can produce and concurrently isolate a water-soluble organic product stereoisomer in the aqueous process stream exiting a multiphase membrane reactor from an organic-soluble achiral precursor that remains in the organic process stream [134]. Achiral precursors which can be biotransformed into chiral products include hydantoins and amino nitrile compounds, which can stereoselectively be converted into such valuable products as amino acids (e.g. D-amino acids and methyl dopa) and amino amides. Another application of this type of multiphase membrane reactor process is the stereoselective hydrolysis of water-insoluble, symmetric diesters to chiral, water-soluble acid ester products, as catalyzed by pig liver esterase. In this application, the achiral diester reactant is fed to the reactor in the organic phase, and the chiral and optically purified acid ester product is withdrawn in the aqueous phase on the opposite side of the membrane [134]. An example is the enantioselective hydrolysis of the substrate cis-1,2-dimethylcyclohex-4-ene-1,2-dicarboxylate (cis-DE) to the chiral product of pharmaceutical interest, (1S,2R)-cyclohex-4-ene-1,2-dicarboxylic acid monomethyl ester ((1S,2R)-ME)): 


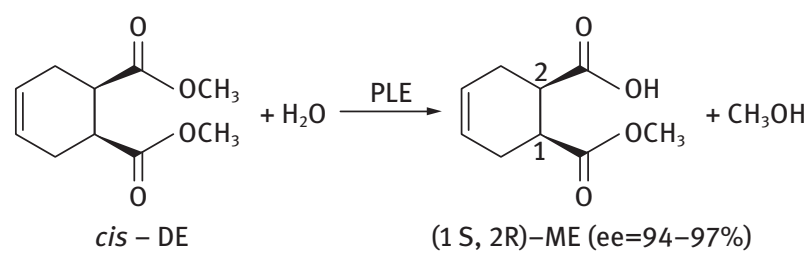

This conversion has been investigated by Sousa et al. [12] using a biphasic hollow fiber membrane reactor containing the immobilized enzyme pig liver esterase. Four covalent attachment techniques (using epoxy, imidazol, amino and carboxylic acid terminal groups) were tested to bind the enzyme to microporous nylon membranes in addition to physical entrapment technique. The physical entrapment method led to the highest retention of enzymatic activity over a prolonged period of time.

The feed stream in multiphase membrane reactor processes may either be organic or aqueous. Fig. 2.29 depicts a process for the resolution of a racemic feed mixture of water-soluble acids and the attendant production of optically purified aqueous acid and organic ester streams. In this process, the mixture is fed in an aqueous solution to one side of an enzyme-activated membrane, and one isomeric component of the racemic acid mixture is stereoselectively combined with a water-soluble alcohol in an enzyme-catalyzed esterification reaction, and the optically enriched ester product is removed by an organic process stream consisting of a water-immiscible organic solvent for the product ester which is fed onto the opposite side of the membrane.

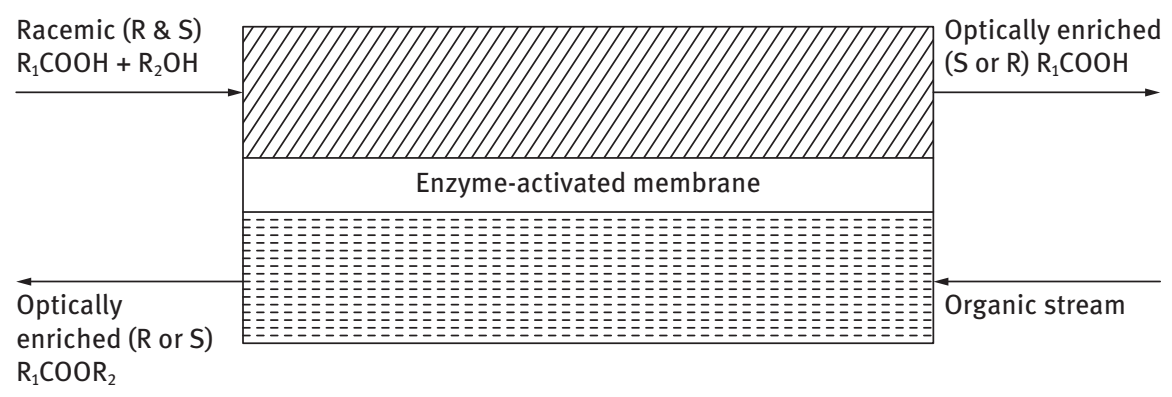

Fig. 2.29: Schematic representation of a method for the resolution of a racemic mixture of watersoluble organic acids fed in an aqueous feed stream [134].

The multiphase enzyme membrane reactors have also been extensively investigated as an alternative method for the enzymatic hydrolysis of triglycerides (e.g. olive oil and butter oil) to fatty acids [94, 140-149]. Hoq et al. [94] have investigated the lipasecatalyzed hydrolysis of olive oil by lipase using hydrophobic polypropylene hollow fiber membrane. Olive oil was fed inside the fibers, a buffer solution containing $18 \%$ glycerol added as a stabilizer was fed outside of the fibers and the enzyme 


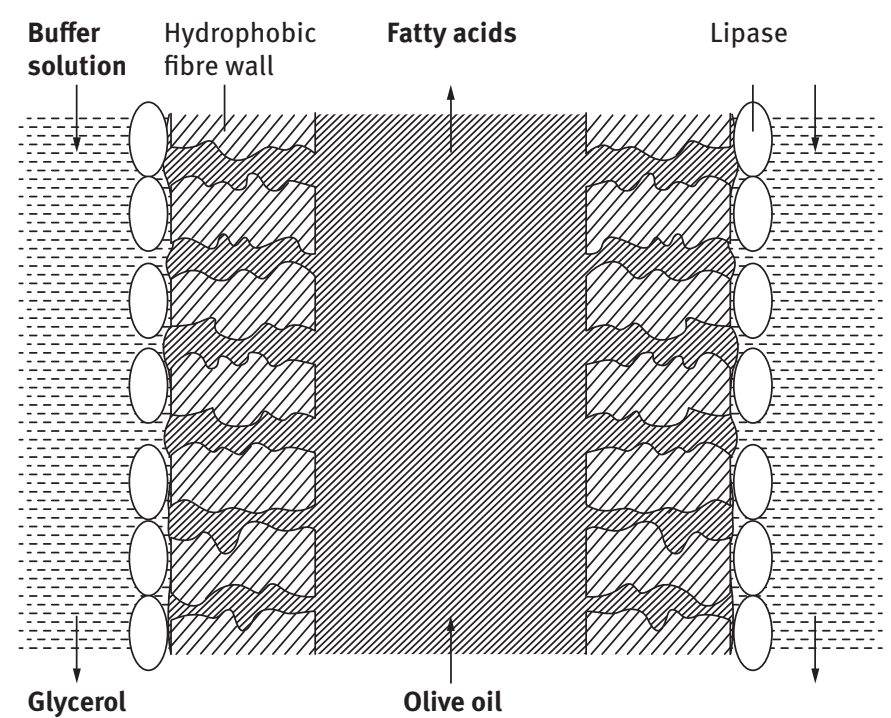

Fig. 2.30: Schematic representation of the enzymatic olive oil conversion in a biphasic hollow fiber bioreactor. Adapted from [94].

was adsorbed on the membrane/aqueous phase interface (Fig. 2.30). Fatty acids were released in the hydrophobic phase and glycerin in the hydrophilic phase.

\subsection{Phase transfer catalysis in multiphase membrane reactors}

\subsubsection{Concept}

Although the examples described above are for enzymatic catalysis with membrane systems, the same approaches can be extended to non-biological catalytic reactions. One example of this is the use of membrane contactors for phase-transfer catalysis (PTC) $[150,151]$. PTC has been widely used in reactions that occur in an organic media where two or more reactants are involved and all but one of these is soluble in the organic phase. The one insoluble reactant is usually an anion dissolved in an aqueous phase. In the absence of the phase transfer catalyst (PTC), the solubility of the anion in the organic phase is generally so small that negligible reaction rates are observed. However, the presence of a PTC in the reaction mixture promotes the transfer of the reacting anion into the organic phase, thus allowing the reaction to proceed at a significantly higher rate.

The mechanism of a phase-transfer catalyzed ion exchange reaction is shown in Fig. 2.31. As illustrated, the catalyst $\mathrm{Q}^{+}$extracts the aqueous phase reactant $\mathrm{Y}^{-}$into the organic phase, where the reaction takes place between the complex $\mathrm{Q}^{+} \mathrm{Y}^{-}$and the 
reactant RX. The products of this reaction are $\mathrm{RY}$ and the complex $\mathrm{Q}^{+} \mathrm{X}^{-}$. Reaction conditions are most favorable when extraction of $\mathrm{Y}^{-}$is highly favored over extraction of $\mathrm{X}^{-}$since this will cause the less soluble complex $\mathrm{Q}^{+} \mathrm{X}^{-}$to be returned to the aqueous phase. This permits $\mathrm{Q}^{+}$to be regenerated and rendered capable of extracting more $\mathrm{Y}^{-}$. Typical phase-transfer catalysts $\mathrm{Q}^{+}$are quaternary ammonium or phosphonium cations, or cyclic polyethers complexed with small cations.
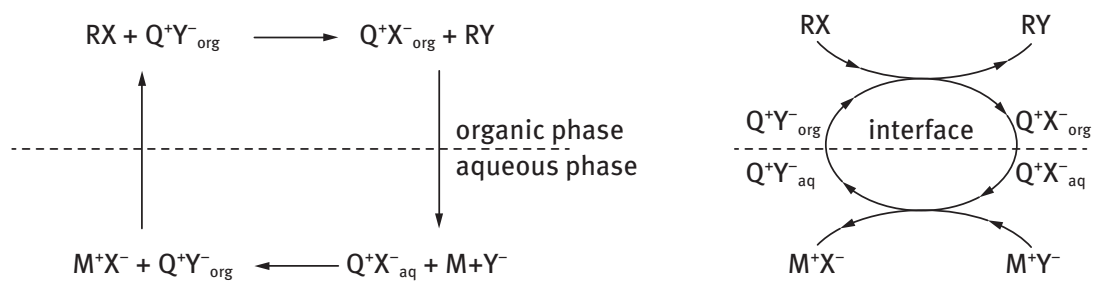

Fig. 2.31: Mechanism of anion displacement reaction in phase transfer catalyzed reaction system.

A key criterion required in a PTC reactor is high interfacial area with little emulsification to enable easy phase separation. The use of membrane modules for a PTC reaction fulfills this criterion as well as offering the advantages of high operating flexibility and easy scale up. Conventionally, PCT is conducted in dispersed-phase systems based on the continual making and breaking of emulsions. A number of problems may arise in these systems such as phase separation and entrainment of one phase into the other, which results in reduced product purity and loss of expensive product and phase transfer catalyst. Another disadvantage of conducting PTC in dispersed-phase systems is its operating inflexibility. Whereas in conventional PTC the interfacial area between the organic and aqueous phases depends on the relative volumes of the two liquid phases (as well as on other operating parameters such as the degree of agitation), in membrane PTC the area of the aqueous/organic interface is fixed and equal to the membrane area. For this reason, membrane PTC reactors can efficiently be operated at more extreme volumetric phase or flow rate ratios than is the case in the absence of a membrane.

\subsubsection{Application}

Phase-transfer catalyzed reactions include nucleophilic substitution reactions, carbene formation, alkylations and alkoxylations, oxidations and reductions, and condensation, elimination and addition reactions. Examples of such reactions are the formation of ring compounds from straight-chain halocarbons, esters from acids and ethers from alcohols; the synthesis of alkylchlorides and other alkyl halides by anion displacement; the alkylation of carbanions; and the oxidation of olefins to carboxylic 
acids [152]. Grigoropoulou et al. [153] have demonstrated the feasibility of the selective oxidation of benzyl alcohols using tetrabutylammonium as a phase transfer catalyst in a flat sheet diaphragm cell containing a porous PTFE membrane to separate the aqueous and organic phase.

Matson and Stanley [150] have employed a flat sheet membrane reactor shown in Fig. 2.32 to conduct a phase phase-transfer catalyzed conversion of bromooctane to iodoctane in the organic solvent chlorobenzene. The reactor was fashioned from two aluminum blocks and a very shallow flow channel $\left(0.05 \times 10 \times 20 \mathrm{~cm}^{3}\right)$ was cut into each block. The flowing streams were isolated by bolting the two blocks together with a hydrophobic PTFE membrane sandwiched in between. The aqueous stream was run at a higher pressure than the organic stream in order to maintain a stable interface at the surface of the hydrophobic membrane adjacent to the aqueous stream. Because of this pressure drop, the membrane was supported by a porous stainless steel screen fastened to the bottom of the organic stream flow channel. Bromooctane in the organic solvent chlorobenzene was reacted with aqueous iodide to form iodoctane in chlorobenzene and aqueous bromide ion. The iodide anion was transferred from the aqueous to organic phase using tetrabutylammonium cation as a phase transfer catalyst. $33 \%$ conversion was observed in steady state at $3.1 \mathrm{ml} / \mathrm{h}$. No entrainment of chlorobenzene in the aqueous effluent could be detected visually and no water was observed in the chlorobenzene effluent after $72 \mathrm{~h}$ of operation without interruption.

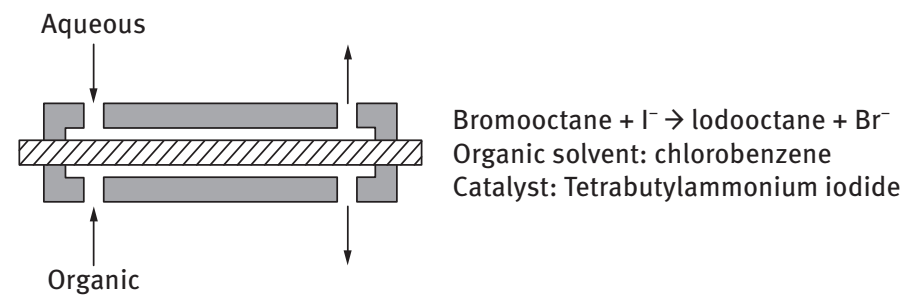

Fig. 2.32: Phase Transfer Catalyst membrane reactor system developed by Matson and Stanley [150].

\subsection{Conclusions}

The technologies and applications reviewed in this chapter document the growing interest in the integration of biochemical reactions into various membrane systems. Membrane bioreactors provide a promising technology for a variety of biochemical conversion/separation processes. It is a consequence of the fact that membrane bioreactors can provide many benefits over conventional reactor designs, such as integration of separation and purification steps with catalytic reactions, much higher order of structural and functional organization, a high degree of control over the fluxes of reactants and products to and from a suspended or membrane-immobilized bio- 
catalyst, etc. In addition to being a separation barrier, membranes can also serve to create a dispersion-free contact of immiscible process streams. The examples of this approach are membrane aeration bioreactors and biphasic aqueous/organic systems. In biphasic systems, two immiscible liquid phases are contacted across a membrane without the necessity of dispersing one immiscible phase within the other. The concept has applications in enzymatic conversions of sparingly water-soluble substrates to water-soluble products and in phase transfer catalysis. The most common enzyme immobilization techniques are reviewed including a novel technique of immobilization of enzymes onto polymer-coated inorganic membranes and the application of these hybrid membranes in the bioreactors operating with a supercritical fluid.

Novel enzyme microcapsules based on advanced functional micro/nano-material have been also discussed, with a special emphasis on microfluidic preparation routes. It was concluded that microfluidic and membrane devices afford the production of highly controllable enzyme-loaded microcapsules, whose semipermeable walls can be composed of asymmetric lipid bilayers, colloidal particles, amphiphilic diblock copolymers and polyelectrolyte multilayers.

\section{References}

[1] Matson SL, Quinn JA. Membrane reactors. In: Ho WS, Sirkar KK, eds. Membrane Handbook. New York, Van Nostrand Reinhold, 1992, 809-832.

[2] Gramer MJ, Poeschl, DM, Conroy, MJ, Hammer, BE. Effect of harvesting protocol on performance of a hollow fiber bioreactor. Biotechnol Bioeng 1999, 65, 334-340.

[3] Walde P, Ichikawa, S. Enzymes inside lipid vesicles: preparation, reactivity and applications, Biomol Eng 2001, 18, 143-177.

[4] Lorenceau E, Utada AS, Link DR, Cristobal G, Joanicot M, Weitz DA. Generation of polymerosomes from double-emulsions. Langmuir, 2005, 21, 9183-9186.

[5] Dinsmore AD, Hsu MF, Nikolaides MG, Marquez M, Bausch AR, Weitz, DA. Colloidosomes: selectively permeable capsules composed of colloidal particles. Science 2002, 298, 10061009.

[6] Peirone M, Ross CJD, Hortelano G, Brash JL, Chang PL. Encapsulation of various recombinant mammalian cell types in different alginate microcapsules. J Biomed Mater Res 1998, 42, 587596.

[7] Cohen S, Yoshioka T, Lucarelli M, Hwang LH, Langer R. Controlled delivery systems for proteins based on poly(lactic/glycolic acid) microspheres. Pharm Res 1991, 8, 713-720.

[8] Bohdziewicz J. Biodegradation of phenol by enzymes from Pseudomonas sp. immobilised onto ultrafiltration membranes. Process Biochem 1998, 33, 811-818.

[9] Alfani F, Albanesi D, Cantarella M, Scardi V. Kinetic properties of gel immobilized acid phosphatase in a tubular membrane reactor. Biotechnol Lett 1981, 3, 309-314.

[10] Liu ZM, Tingry S, Innocent C, Durand J, Xua ZK, Seta P. Modification of microfiltration polypropylene membranes by allylamine plasma treatment. Influence of the attachment route on peroxidase immobilization and enzyme efficiency. Enzyme Microb Technol 2006, 39, 868-876.

[11] Heng $\mathrm{MH}$, Glatz CE. Ion exchange immobilization of changed $\beta$-galactosidase fusions for lactose hydrolysis. Biotechnol Bioeng 2004, 44, 745-752. 
[12] Sousa HA, Rodrigues C, Klein E, Afonso, CAM, Crespo JG. Immobilisation of pig liver esterase in hollow fibre membranes. Enzyme Microb Technol 2001, 29, 625-634.

[13] Simon S. Cross-linked enzyme membrane. US Patent 1981, 4,251,631.

[14] Giorno L, Drioli E. Biocatalytic membrane reactors: applications and perspectives. Trends Biotechnol 2000, 18, 339-349.

[15] Giorno L, Molinari R, Drioli E, Bianchi D, Cestic P. Performance of a biphasic organic/aqueous hollow fibre reactor using immobilized lipase. J Chem Technol Biotechnol 1995, 64, 345-352.

[16] Sakaki K, Hara S, Itoh N. Optical resolution of racemic 2-hydroxy octanoic acid using biphasic enzyme membrane reactor. Desalination 2002, 149, 247-252.

[17] Pankhania M, Brindle K, Stephenson T. Membrane aeration bioreactors for wastewater treatment: completely mixed and plug-fow operation. Chem Eng J 1999, 73, 131-136.

[18] Splendiani A, Moreira de Sa, JAGC, Jorge R, Nicolella C, Livingston AG, Hughes K, Cook S. Development of an extractive membrane bioreactor for degradation of 3 chloro-4 methylaniline: from lab bench to pilot scale. Environ Prog 2000, 19, 18-27.

[19] Fabiani C, Giubileo G, Pizzichini M, Violante V. Steady state modelling of a hollow fiber enzymatic reactor. Biotechnol Bioeng 1987, 30, 458-461.

[20] López C, Mielgo I, Moreira MT, Feijoo G, Lema JM. Enzymatic membrane reactors for biodegradation of recalcitrant compunds. Applications to dye decolourisation. J Biotechnol 2002, 99, 249-257.

[21] Prazeres DMF, Cabral JMS. Enzymatic membrane reactors. In: Cabral JMS, Mota M, Tramper J, eds. Multiphase Bioreactor Design. London, Taylor \& Francis, 2001, 135-180.

[22] Knez $\check{Z}$, Habulin M, Primožič $M$. Hydrolases in supercritical $\mathrm{CO}_{2}$ and their use in a highpressure membrane reactor. Bioprocess Biosyst Eng 2003, 25, 279-284.

[23] Habulin M, Primožič M. Knez ž. Enzymatic reactions in high-pressure membrane reactors. Ind Eng Chem Res 2005, 44, 9619-9625.

[24] Stephenson T, Brindle K, Judd S, Jefferson B. Membrane bioreactors for wastewater treatment. IWA Publishing, London, UK (2000).

[25] Fane AG, Chang S, Chardon E. Submerged hollow fibre membrane module - design options and operational considerations. Desalination 2002, 146, 231-236.

[26] Mack C, Burgess JE, Duncan JR. Membrane bioreactors for metal recovery from wastewater: A review. Water SA 2004, 30, 521-532.

[27] Vladisavljević GT, Mitrović MV. Pressure drops and hydraulic resistances in a three-phase hollow fiber membrane contactor with frame elements. Chem Eng Process 2001, 40, 3-11.

[28] Ozdemir SS, Buonomenna MG, Drioli E. Catalytic polymeric membranes: Preparation and application. Appl Catal A-Gen 2006, 307, 167-183.

[29] Wichmann R, Wandrey C, Bückmann AF, Kula MR. Continuous enzymatic transformation in an enzyme membrane reactor with simultaneous NAD(H) regeneration. Biotechnol Bioeng 1981, 23, 2789-2802.

[30] Kulbe KD, Howaldt MW, Schmidt K, Röthig TR, Chmiel H. Rejection and continuous regeneration of the native coenzyme $\mathrm{NAD}(\mathrm{P}) \mathrm{H}$ in a charged ultrafiltration membrane enzyme reactor. Ann NY Acad Sci 1990, 613, 820-826.

[31] Shettigar UR. Multi-enzyme bioreactor therapy for cancer. US Patent 4,955,857, 1990.

[32] Ameer G, Langer Jr RS, Rupnick M, Ploegh HL, Grovender E. Apparatus for treating whole blood comprising concentric cylinders defining an annulus therebetween. US Patent 6,099,730, 2000.

[33] Allen JW, Hassanein T, Bhatia SN. Advances in bioartificial liver devices. Hepatology, 2001, 34, 447-455.

[34] Ohgawara H, Hirotani S. Miyazaki J, Teraoka S. Membrane immunoisolation of a diffusion chamber for bioarticifial pancreas. Artif Organs 1998, 22, 788-794. 
[35] Guadix A, Camacho F, Guadix EM. Production of whey protein hydrolysates with reduced allergenicity in a stable membrane reactor. J Food Eng 2006, 72, 398-405.

[36] Cantarella M, Cantarella L, Gallifuoco A, Intellini R, Kaplan O, Spera A, Martínková L. Amidase-catalyzed production of nicotinic acid in batch and continuous stirred membrane reactors. Enzyme Microb Technol 2008, 42, 222-229.

[37] Satory M, Fürlinger M, Haltrich D, Kulbe KD, Pittner F, Nidetzky B. Continuous enzymatic production of lactobionic acid using glucose-fructose oxidoreductase in an ultrafiltration membrane reactor. Biotechnol Lett 1997, 19, 1205-1208.

[38] Prata-Vidal M, Bouhallab S, Henry G, Aimar P. An experimental study of caseinomacropeptide hydrolysis by trypsin in a continuous membrane reactor. Biochem Eng J 2001, 8, 195-202.

[39] Martin-Orue C, Henry G, Bouhallab S. Tryptic hydrolysis of ?-caseinomacropeptide: Control of the enzymatic reaction in a continuous membrane reactor. Enzyme Microb Technol 1999, 24, 173-180.

[40] Mameri N, Hamdache F, Abdi N, Belhocine D, Grib H, Lounici H, Piron DL. Enzymatic saccharification of olive mill solid residue in a membrane reactor. J Membr Sci 2000, 178, 121-130.

[41] López-Ulibarri R, Hall GM. Saccharification of cassava flour starch in a hollow-fiber membrane reactor. Enzyme Microb Technol 1997, 21, 398-404.

[42] Singh N, Cheryan M. Membrane technology in corn refining and bioproduct-processing. Starch 1998, 50, 16-23.

[43] Jurado E, Camacho F, Luzon G, Vicaria JM. Influence of the hollow-fibre membrane on the stability of $\alpha$-galactosidase and on lactose hydrolysis. Kinetic models including adsorption of the enzyme onto the membrane. Enzyme Microb Technol 2006, 39, 1008-1015.

[44] Gray GM, Olson AC. Hydrolysis of high levels of naringin in grapefruit juice using a hollow fiber naringinase reactor. J Agric Food Chem 1981, 29, 1298-1301.

[45] Bélafi-Bakó K, Eszterle M, Kiss K, Nemestóthy N, Gubicza L. Hydrolysis of pectin by Aspergillus niger polygalacturonase in a membrane bioreactor, J Food Eng 2007, 78, 438-442.

[46] Rodriguez-Nogales JM, Ortega O, Perez-Mateos M, Busto MD. Pectin hydrolysis in a free enzyme membrane reactor: An approach to the wine and juice clarification. Food Chem 2008, 107, 112-119.

[47] Tomotani EJ, Vitolo M. Production of high-fructose syrup using immobilized invertase in a membrane reactor. J Food Eng 2007, 80, 662-667.

[48] Nidetzky B, Neuhauser W, Haltrich D, Kulbe KD. Continuous enzymatic production of xylitol with simultaneous coenzyme regeneration in a charged membrane reactor. Biotechnol Bioeng 1996, 52, 387-396.

[49] Kuo CH, Chen CC, Chiang BH. Process characteristics of hydrolysis of chitosan in a continuous enzymatic membrane reactor. J Food Sci 2004, 69, 332-337.

[50] Deeslie WD, Cheryan M. Functional properties of soy protein hydrolysates from a continuous ultrafiltration reactor. J Agric Food Chem 1988, 36, 26-31.

[51] Holtzhausen L. The war for water. Fighting the battle for the last drop. WASE 2002, 22, 26-29.

[52] Bodzek M, Bohdziewicz J, Kowalska M. Preparation of membrane-immobilised enzymes for phenol decomposition. J Chem Technol Biotechnol. 1994, 61, 231-239.

[53] Edwards W, Bownes R, Leukes WD, Jacobs EP, Sanderson R, Rose PD, Burton, SG. A capillary membrane bioreactor using immobilized polyphenol oxidase for the removal of phenols from industrial effluents. Enzyme Microb Technol 1999, 24, 209-217.

[54] Lante A, Crapisi A, Krastanov A, Spettoli P. Biodegradation of phenols by laccase immobilised in a membrane reactor. Process Biochem 2000, 36, 51-58.

[55] Jolivalt C, Brenon S, Caminade E, Mougin C, Pontié M. Immobilization of laccase from Trametes versicolor on a modified PVDF microfiltration membrane: characterization of the grafted 
support and application in removing a phenylurea pesticide in wastewater. J Membr Sci 2000, 180, 103-113.

[56] Kojima H, Ogawa M, Tamai S, Yamada M, Hasunuma M. Oxidation of glucose oxidase entrapped in hollow fiber membrane. J Chem Eng Jpn 1995, 28, 623-626.

[57] Liese A, Karutz M, Kamphuis J, Wandrey C, Kragl U. Enzymatic resolution of 1-phenyl1,2-ethanediol by enantioselective oxydation: overcoming product inhibition by continuous extraction. Biotechnol Bioeng 1996, 51, 544-550.

[58] Flock C, Bassi A, Gijzen M, Removal of aqueous phenol and 2-chlorophenol with purified soybean peroxidase and raw soybean hulls. J Chem Technol Biotechnol 1999, 74, 303-309.

[59] Gallifuoco A, Alfani F, Cantarella M, Viparelli P. Studying enzyme-calalyzed depolymerization in continuous reactors. Ind Eng Chem Res 2001, 40, 5184-5190.

[60] Brindle K, Stephenson T. The application of membrane biological reactors for the treatment of wastewaters. Biotechnol Bioeng 1996, 49, 601-610.

[61] Livingston AG. Extractive membrane bioreactors: a new process technology for detoxifying chemical industry wastewaters. I Chem Technol Biotechnol 1994, 60, 117-124.

[62] Brindle K, Stephenson T, Semmens MJ. Nitrification and oxygen utilisation in a membrane aeration bioreactor. J Membr Sci 1998, 144, 197-209.

[63] Freitas Dos Santos, LM, Livingston AG. Novel membrane bioreactor for detoxification of VOC wastewaters: biodegradation of 1, 2-dichloroethane. Water Res 1995, 29, 179-194.

[64] Su WW, Haram HS, Humphrey AE. Optimal design of the tubular microporous membrane aerator for shear-sensitive cell cultures. Biotechnol Prog 1992, 8, 19-24.

[65] Yamagiwa K, Ohkawa A. Simultaneous organic carbon removal and nitrification by biofilm formed on oxygen enrichment membrane. J Chem Eng Jpn 1994, 27, 638-643.

[66] Kniebusch MM, Wilderer PA, Behling RD. Immobilisation of cells on gas permeable membranes. In: Physiology of Immobilised Cells. Amsterdam, The Netherlands, Elsevier Science, 1990, 149-160.

[67] Attaway H, Gooding CH, Schmidt MG. Comparison of microporous and nonporous membrane bioreactor systems for the treatment of BTEX in vapor streams. J Ind Microbiol Biotechnol 2002, 28, 245-251.

[68] Timberlake DI, Strand SE, Williamson KJ. Combined aerobic heterotrophic oxidation, nitrification and denitrification in a permeable support biofilm. Water Res 1988, 22, 1513-1517.

[69] Hirasa O, Ichijo H, Yamauchi A. Preparation of new support for immobilisation of activated sludge. J Ferment Bioeng 1991, 71, 376-378.

[70] Attaway H, Gooding CH, Schmidt MG. Biodegradation of BTEX vapors in a silicone membrane bioreactor system. J Ind Microbiol Biotechnol 2001, 26, 316-325.

[71] Livingstone AG, Arcangeli JP, Boam AT, Zhang S, Marangon M, Freitas Dos Santos LM. Extractive membrane bioreactors for detoxification of chemical industry wastes: Process development. J Membr Sci 1998, 151, 29-44.

[72] Freitas dos Santos LM, Livingston AG. Membrane-attached biofilms for VOC wastewater treatment II: effect of biofilm thickness on performance. Biotechnol Bioeng 1995, 47, 90-95.

[73] Debus 0, Wanner 0. Degradation of xylene by biofilm growing on a gas-permeable membrane. Water Sci Technol 1992, 26, 607-616.

[74] Reij MW, de Gooijer KD, de Bont JAM, Hartmans S. Membrane bioreactor with porous hydrophobic membrane as gas-liquid contactor for waste gas treatment. Biotechnol Bioeng 1995 , 45, 105-115.

[75] Nicolella C, Pavasant P, Livingston AG. Substrate counter diffusion and reaction in membrane-attached biofilms: mathematical analysis of rate limiting mechanisms. Chem Eng Sci 2000, 55, 1385-1398. 
[76] Strachan LF, Freitas dos Santos LM, Leak DJ, Livingston AG. Minimisation of biomass in an extractive membrane bioreactor. Water Sci Technol 1996, 34, 273-280.

[77] Nicolella C, Garcia Appendini IC, Zhang SF, Livingston AG. Control of membrane attached biofilms in extractive membrane bioreactor. Water Sci Technol 2000, 41, 227-234.

[78] Splendiani A, Nicolella C, Livingston AG. A novel biphasic extractive membrane bioreactor for minimization of membrane-attached biofilms. Biotechnol Bioeng 2003, 83, 8-19.

[79] Emanuelsson EAC, Arcangeli JP, Livingston AG. The anoxic extractive membrane bioreactor. Water Res 2003, 37, 1231-1238.

[80] Splendiani A, Livingston AG, Nicolella C. Control of membrane-attached biofilms using surfactants. Biotechnol Bioeng 2006, 94, 15-23.

[81] Buenrostro-Zagal JF, Ramírez-Oliva A, Caffarel-Méndez S, Schettino-Bermúdez B, PoggiVaraldo HM. Treatment of a 2,4- dichlorophenoxyacetic acid (2,4-D) contaminated wastewater in a membrane bioreactor. Water Sci Technol 2000, 42, 185-192.

[82] Jorge RMF, Livingston AG. Biological treatment of an alternating source of organic compounds in a single tube extractive membrane bioreactor. J Chem Technol Biotechnol 2000, 75, 11741182.

[83] Brookes PR, Livingston AG. Biological detoxification of a 3-chloronitrobenzene manufacture wastewater in an extractive membrane bioreactor. Water Res 1994, 28, 1347-1354.

[84] Brookes PR, Livingston AG. Point source detoxification of an industrially produced 3,4-dichloroaniline-manufacture wastewater using a membrane bioreactor. Appl Microbiol Biot 1993, 39, 764-771.

[85] Brookes PR, Livingston AG. Aqueous-aqueous extraction of organic pollutants through tubular silicone rubber membranes. J Membr Sci 1995, 104, 119-137.

[86] Liu W, Howell JA, Arnot TC, Scott JA. Extraction membrane bioreactor for treating priority pollutants in the presence of inorganics. Membrane Tech 2001, 133, 4-7.

[87] Liu W, Howell JA, Arnot TC, Scott JE. A novel extractive membrane bioreactor for treating biorefractory organic pollutants in the presence of high concentrations of inorganics: application to a synthetic acidic effluent containing high concentrations of chlorophenol and salt .J Membr Sci 2001, 181, 127-140.

[88] Mateo C, Palomo JM, Fernandez-Lorente G, Guisan JM, Fernandez-Lafuente R. Improvement of enzyme activity, stability and selectivity via immobilization techniques. Enzyme Microb Tech 2007, 40, 1451-1463.

[89] Zhang YT, Zhang L, Chen HL, Zhang HM. Selective separation of low concentration $\mathrm{CO}_{2}$ using hydrogel immobilized CA enzyme based hollow fiber membrane reactors. Chem Eng Sci 2010, 65, 3199-3207.

[90] Ceynowa J, Koter I. Methyl- $\beta$-cyclodextrin assisted enantioselective ester hydrolysis catalyzed by lipase immobilized in a polymer membrane. Sep Sci Technol 2001, 36, 2885-2898.

[91] Lopez JL, Matson SL. A multiphase/extractive enzyme membrane reactor for production of diltiazem chiral intermediate. J Membr Sci 1997, 125, 189-211.

[92] Cioci F, Lavecchia R, Mazzocchi P. An enzymatic membrane reactor for extracorporeal blood oxygenation. Chem Eng Sci 1999, 54, 3217-3223.

[93] Díaz EG, Catana R, Ferreira BS, Luque S, Fernandes P, Cabral MS. Towards the development of a membrane reactor for enzymatic inulin hydrolysis. J Membr Sci 2006, 273, 152-158.

[94] Hoq MM, Yamane T, Shimizu S. Role of oleic acid solubilized in buffer-glycerol solution on adsorbed lipase during continuous hydrolysis of olive oil in a microporous hydrophobic membrane bioreactor. Enzyme Microb Technol 1986, 8, 236-240.

[95] Hicke HG, Becker M, Paulke BR, Ulbricht M. Covalently coupled nanoparticles in capillary pores as enzyme carrier and as turbulence promoter to facilitate enzymatic polymerizations in flow-through enzyme-membrane reactors. J Membr Sci 2006, 282, 413-422. 
[96] Long WS, Kamaruddin AH, Bhatia S. Enzyme kinetics of kinetic resolution of racemic ibuprofen ester using enzymatic membrane reactor. Chem Eng Sci 2005, 60, 4957-4970.

[97] Matson SL. Multiphase asymmetric membrane reactor systems. US Patent 4,795,704, 1989.

[98] Vladisavljević GT, Williams RA. Recent developments in manufacturing emulsions and particulate products using membranes. Adv Colloid Interface Sci 2005, 113, 1-20.

[99] Pautot S, Frisken BJ, Weitz DA. Engineering asymmetric vesicles. PNAS, 2003, 100, 1071810721.

[100] Utada AS, Lorenceau E, Link DR, Kaplan PD, Stone HA, Weitz DA. Monodisperse double emulsions generated from a microcapillary device. Science, 2005, 308, 537-541.

[101] Hoare TR, Kohane DS. Hydrogels in drug delivery: Progress and challenges. Polymer 2008, 49, 1993-2007.

[102] Zhang H, Tumarkin E, Sullan RMA, Walker GC, Kumacheva E. Exploring microfluidic routes to microgels of biological polymers. Macromol Rapid Commun 2007, 28, 527-538.

[103] Sakai S, Hashimoto I, Ogushi Y, Kawakami K. Peroxidase-catalyzed cell encapsulation in subsieve-size capsules of alginate with phenol moieties in water-immiscible fluid dissolving $\mathrm{H}_{2} \mathrm{O}_{2}$. Biomacromolecules $2007,8,2622-2626$.

[104] Prodanović R, Ostafe R, Scacioc A, Schwaneberg U. Ultrahigh-throughput screening system for directed glucose oxidase evolution in yeast cells. Comb Chem High Throughput Screen 2011, 14, 55-60.

[105] Zhang L, Su Y, Zheng Y, Jiang Z, Shi J, Zhu Y, Jiang Y. Sandwich-structured enzyme membrane reactor for efficient conversion of maltose into isomaltooligosaccharides. Bioresource Technol 2010, 101, 9144-9149.

[106] Belleville MP, Lozano P, Iborra JL, Rios GM. Preparation of hybrid membranes for enzymatic reaction. Sep Purif Technol 2001, 25, 229-233.

[107] Lozano P, De Diego T, Belleville MP, Rios GM, Iborra JL. A dynamic membrane reactor with immobilized $\alpha$-chymotrypsin for continuous kyotorphin synthesis in organic media. Biotechnol Lett 2000, 22, 771-775.

[108] Lozano P, Pérez-Marín AB, De Diego T, Gómez D, Paolucci-Jeanjean D, Belleville MP, Rios GM, Iborra JL. Active membranes coated with Candida antartica Lipase B: preparation and application for continuous butyl butyrate synthesis in organic media. J Membr Sci 2002, 201, 55-64.

[109] Bullon J, Belleville MP, Rios GM. Preparation of gelatin formed-in place membranes: effect of working conditions and substrates, J Membr Sci 2000, 168, 159-165.

[110] Rios GM, Belleville MP, Paolucci D, Sanches J. Progress in enzymatic membrane reactors. J Membr Sci 2004, 242, 189-196.

[111] Lozano P, Víllora G, Gómez D, Gayo AB, Sánchez-Conesa JA, Rubio M, Iborra JL. Membrane reactor with immobilized Candida antarctica lipase B for ester synthesis in supercritical carbon dioxide. J Supercrit Fluid 2004, 29, 121-128.

[112] Gumi T, Paolucci-Jeanjean D, Belleville MP, Rios GM. Enzymatic membrane reactor in supercritical carbon dioxide. Desalination 2006, 200, 505-506.

[113] Mori M, Gomez Garcia R, Belleville MP, Paolucci-Jeanjean D, Sanchez J, Lozano P, Vaultier M, Rios G. A new way to conduct enzymatic synthesis in an active membrane using ionic liquids as catalyst support. Catal Today 2005, 104, 313-317.

[114] Pomier E, Galy J, Paolucci-Jeanjean D, Pina M, Sarrade S, Rios GM. A new reactor design combining enzyme, membrane and $\mathrm{SC} \mathrm{CO}_{2}$ : application to castor oil modification. J Membr Sci 2005, 249, 127-132.

[115] Pomier E, Delebecque N, Paolucci-Jeanjean D, Pina M, Sarrade S, Rios GM. Effect of working conditions on vegetable oil transformation in an enzymatic reactor combining membrane and supercritical $\mathrm{CO}_{2}$. J Supercrit Fluid 2007, 41, 380-385. 
[116] Matson SL, Quinn JA. Membrane reactors in bioprocessing. Ann NY Acad Sci 1986, 469, 152-165.

[117] Matson SL, Quinn JA. Method and apparatus for conducting catalytic reactions with simultaneous product separation and recovery. US Patent 4,786,597, 1988.

[118] Laćan G, Satyamurthy N, Barrio JR. (E) and (Z)- $\beta$-fluoromethylene- $m$-tyrosines: Resolution and determination of configuration. Tetrahedron: Asymmetry 1995, 6, 525-536.

[119] Abe K, Goto M, Nakashio F. Novel optical resolution of phenylalanine racemate utilizing enzyme reaction and membrane extraction. Sep Sci Technol 1997, 32, 1921-1935.

[120] Mzengeza S, Venkatachalam TK, Rajagopal S, Diksic M. Synthesis of enantiomerically pure $\alpha-\left[{ }^{14} \mathrm{C}\right]$ methyl-L-tryptophan. Appl Radiat Isotopes 1993, 44, 1167-1172.

[121] Jadaud P, Wainer IW. The stereochemical resolution of the enantiomers of aspartame on an immobilized alpha-chymotrypsin HPLC chiral stationary phase: the effect of mobile-phase composition and enzyme activity. Chirality 1990, 2, 32-37.

[122] Matta MS. Method for preparing L-dopa and novels compounds useful therein. US Patent 3,878,043, 1975 .

[123] Miyazawa T. Enzymatic resolution of amino acids via ester hydrolysis. Amino Acids 1999, 16, 191-213.

[124] Lopez JL, Matson SL, Stanley TS, Quinn JA. Liquid/liquid extractive membrane reactors. In: Mattiasson B, Holst O, eds. Extractive Bioconversions. New York, Marcel Dekker, 1988, 27-66.

[125] Marchese J, Lopez JL, Quinn JA. Facilitated transport of benzylpenicillin through immobilized liquid membrane. J Chem Technol Biotechnol 1989, 46, 149-159.

[126] Belfort G. Membranes and bioreactors: a technical challenge in biotechnology. Biotechnol Bioeng 1989, 33, 1047-1066.

[127] Matson SL, Lopez JL. Multiphase membrane reactors for enzymatic resolution: Diffusional effects on stereoselectivity. In: Sikdar SK, Todd P, Bier M, eds. Frontiers in Bioprocessing. Boca Raton, FL, CRC Press, 1989, 391-403.

[128] Lopez JL, Wald SA, Matson SL, Quinn JA. Multiphase membrane reactors for separating stereoisomers. NY Acad Sci 1991, 613, 155-166.

[129] Lilly MD. Two-liquid-phase biocatalytic reactions. J Chem Technol Biotechnol 1982, 32, 162-169.

[130] Giorno L, Piacentini E, Mazzei R, Drioli E. Membrane emulsification as a novel method to distribute phase-transfer biocatalysts at the oil/water interface in bioorganic reactions. J Membr Sci 2008, 317, 19-25.

[131] Li N, Sakaki K. Performance of an emulsion enzyme membrane reactor combined with premix membrane emulsification for lipase-catalyzed resolution of enantiomers. J Membr Sci 2008, 314, 183-192.

[132] Zaks A, Klibanov AM. Enzymatic catalysis in nonaqueous solvents. J Biol Chem 1988, 263, 3194-3201.

[133] Han D, Rhee JS. Characteristics of lipase-catalyzed hydrolysis of olive oil in AOT-isooctane reversed micelles. Biotechnol Bioeng 1986, 28, 1250-1255.

[134] Matson SL. Method for resolution of stereoisomers in multiphase and extractive membrane reactors. US Patent 4,800,162, 1989.

[135] Furui M, Furutani T, Shibatani, T, Nakamoto Y, Mori T. A membrane bioreactor combined with crystallizer for production of optically active $(2 R, 3 S)-3-(-4$ methoxyphenyl)-glycidic acid methyl ester. J Ferment Bioeng 1996, 81, 21-25.

[136] Sakaki K, Giorno L, Drioli E. Lipase-catalyzed optical resolution of racemic naproxen in biphasic enzyme membrane reactors. J Membr Sci 2001, 184, 27-38. 
[137] Li N, Giorno L, Drioli E. Effect of immobilization site and membrane materials on multiphasic enantiocatalytic enzyme membrane reactors. Ann NY Acad Sci 2003, 984, 436-452.

[138] Giorno L, Drioli E. Catalytic behaviour of lipase free and immobilized in biphasic membrane reactor with different low water-soluble substrates. J Chem Technol Biotechnol 1997, 69, 11-14.

[139] Wu DR, Cramer SM, Belfort G. Kinetic resolution of racemic glycidyl butyrate using a multiphase membrane enzyme reactor: Experiments and model verification. Biotechnol Bioeng 2004, 41, 979-990.

[140] Bélafi-Bakó K, Dombi Á, Szabó L, Nagy E. Triacylglycerol hydrolysis by lipase in a flat membrane bioreactor. Biotechnol Tech 1994, 8, 671-674.

[141] Malcata FX, Hill Jr CG, Amundson CH. Use of a lipase immobilized in a membrane reactor to hydrolyze the glycerides of butteroil. Biotechnol Bioeng 1991, 38, 853-868.

[142] Malcata FX, Garcia HS, Hill Jr CG, Amundson CH. Hydrolysis of butteroil by immobilized lipase using a hollow-fiber reactor: Part I. Lipase adsorption studies. Biootechnol Bioeng 1992, 39, 647-657.

[143] Malcata FX, Hill Jr CG, Amundson CH. Hydrolysis of butteroil by immobilized lipase using a hollow-fiber reactor: Part II. Uniresponse kinetic studies. Biotechnol Bioeng 1992, 39, $984-$ 1001.

[144] Molinari R, Drioli E, Barbieri G. Membrane reactor in fatty acid production. J Membr Sci 1988, 36, 525-534.

[145] Molinari R, Santoro ME, Drioli E. Study and comparison of two enzyme membrane reactors for fatty acids and glycerol production. Ind Eng Chem Res 1994, 33, 2591-2599.

[146] Taylor F, Kurantz MJ, Craig Jr JC. Kinetics of continuous hydrolysis of tallow in a multi-layered flat-plate immobilized lipase reactor. J Am Oil Chem Soc 1992, 69, 591-594.

[147] Pronk W, Kerkhof PJAM, van Helden C, van't Riet K. The hydrolysis of triglycerides by immobilized lipase in a hydrophilic membrane reactor. Biotechnol Bioeng 1988, 32, 512-518.

[148] Pronk W, Boswinkel G, van't Riet K. Parameters influencing hydrolysis kinetics of lipase in a hydrophilic membrane reactor. Enzyme Microbiol Technol 1992, 14, 214-220.

[149] Sroka Z. The activity of lipase from Rhizopus $s p$. in native form and after immobilization on hollow-fiber membranes. J Membr Sci 1994, 97, 209-214.

[150] Matson SL, Stanley TJ. Phase transfer catalysis. US Patent 4,754,089, 1988.

[151] Stanley TJ, Quinn JA. Phase-transfer catalysis in a membrane reactor. Chem Eng Sci 1987, 42, 2313-2324.

[152] Freedman HH. Industrial applications of phase transfer catalysis (PTC): past, present and future. Pure Appl Chem 1986, 58, 857-868.

[153] Grigoropoulou G, Clark JH, Hall DW, Scott K. The selective oxidation of benzyl alcohols in a membrane reactor. Chem Commun 2001, 547-548. 